\title{
A review of the species of Crenicichla (Teleostei: Cichlidae) from the Atlantic coastal rivers of southeastern Brazil from Bahia to Rio Grande do Sul States, with descriptions of three new species
}

\author{
Sven O. Kullander* and Carlos A. Santos de Lucena**
}

\begin{abstract}
Six species of Crenicichla, three of which are new, are recognized from the Atlantic coastal rivers of souhteastern Brazil from the state of Bahia south to the state of Rio Grande do Sul: C. mucuryna (upper rio Mucuri, Minas Gerais), C. lacustris (from the rio Paraíba do Sul north to the rio Buranhem, Bahia), C. iguapina, new species (rio Ribeira de Iguape), C. tingui, new species (from the rio Itapocu to the rio Nhundiaquara drainage), C. maculata, new species (lagoa dos Quadros, rio Maquiné, Rio Grande do Sul to rio Itapocu, Santa Catarina drainages), and Crenicichla punctata (laguna dos Patos basin). Crenicichla biocellata is a synonym of C. lacustris; and also a secondary homonym of Sparus biocellatus, a synonym of C. saxatilis. Crenicichla dorsocellata is also a synonym of $C$. lacustris.

Seis espécies de Crenicichla, sendo três novas, são reconhecidas dos rios costeiros do sudeste brasileiro, desde o estado da Bahia para o sul, até o estado do Rio Grande do Sul: C. mисuryna (parte superior do rio Mucuri, Minas Gerais), C. lacustris (do rio Paraíba do Sul para o norte até o rio Buranhem, Bahia), C. iguapina, esp. nova (do rio Ribeira de Iguape), C. tingui, esp. nova (das drenagens do rio Itapocu, Santa Catarina ao rio Nhundiaquara, Paraná), C. maculata, esp. nova (lagoa dos Quadros, rio Maquiné, Rio Grande do Sul ao rio Itapocu, Santa Catarina) e Crenicichla punctata (sistema da laguna dos Patos). Crenicichla biocellata e C. dorsocellata são consideradas sinônimos de C. lacustris. A primeira é também um homônimo secundário de Sparus biocellatus que por sua vez é sinônimo de Crenicichla saxatilis.
\end{abstract}

Key words: Crenicichla tingui, Crenicichla iguapina, Crenicichla maculata, Systematics, Conservation.

\section{Introduction}

The cichlid genus Crenicichla, comprising 74 valid species (Kullander, 2003), is currently recognized as the most species rich genus of cichlids. It is found over most of tropical and subtropical cis-Andean South America. The genus has been revised repeatedly (Pellegrin, 1904; Regan, 1905, 1913; Ploeg, 1991), and a large number of papers have added new species or revise smaller units, most recently Lucena \& Azevedo (1989), Lucena \& Kullander (1992), and Kullander(1990a,b; 1991; 1997).

Six species of Crenicichla have been described from the rivers draining to the Atlantic coast of southeastern Brazil between the States of Rio Grande do Sul (laguna dos Patos system) and Bahia (city of Salvador), viz. Crenicichla lacustris Castelnau (1855) from "Dique, ou étang près de Bahia;" $C$. punctata Hensel (1870) from the lago Guaíba and C. polysticta Hensel (1870) from the rio Cadeia, both localities in Rio Grande do Sul; C. dorsocellata Haseman (1911) from Campos, rio Paraíba do Sul, State of Rio de Janeiro; C. biocellata Ihering (1914) from Porto Cachoeiro (now Santa Leopoldina), State of Espírito Santo, and C. mucuryna Ihering (1914) from the rio Todos os Santos, a tributary of the rio Mucuri in the State of Minas Gerais.

These six nominal species have for the most part been synonymized under C. lacustris (e.g., Ploeg, 1991), or treated as a systematically poorly understood C. lacustris group (e.g., Kullander, 1982), vaguely diagnosed by the absence of pterotic serrations (vs. presence in C. wallacii group), moderate scale counts, 47-70 (vs. 90 or more in the C. lugubris and $C$. acutirostris groups), presence of red belly in breeding females and absence of humeral ocellus ( $v s$. present in $C$. saxatilis group), 3 to 5 rows of depressible teeth and without vertical bars in any ontogenetic stage (vs. often with fewer, more firmly implanted teeth and always with a colour pattern

\footnotetext{
* Department of Vertebrate Zoology. Swedish Museum of Natural History, P.O. BOX 50007, SE-104 05 Stockholm, Sweden. e-mail: sven.kullander@nrm.se

** Bolsista de Produtividade CNPq. Pontifícia Universidade Católica do Rio Grande do Sul, Museu de Ciências e Tecnologia. Laboratório de Ictiologia, Av. Ipiranga 6681, prédio 40, 90619-900 Porto Alegre, RS, Brazil. e-mail: lucena@pucrs.br
} 
consisting of vertical bars from juvenile to adult in the $C$. reticulata group); serrated preopercular margin (vs. smooth in C. missioneira group; C. celidochilus Casciotta, 1987 is tentatively included in this group by Lucena \& Kullander, 1992), maxilla just reaching to the vertical anterior of orbit ( $v s$. beyond the same vertical in C. scottii group), and predorsal scales cycloid and normal size eyes ( $v s$. ctenoid predorsal scales and extremely large eyes in C. macrophthalma Heckel, 1840). Besides the nominal species cited above, Ploeg (1991) includes C. niederleinii (Holmberg, 1899); C. jupiaensis Britski \& Luengo, 1968; C. iguassuensis Haseman, 1911; C. jaguarensis Haseman, 1911, and C. haroldoi Luengo \& Britski, 1974 in the C. lacustris group.

Lucena \& Kullander (1992) demonstrated that the lacustris group as hitherto understood is not monophyletic, and Lucena \& Azevedo (1989) showed that C. punctata Hensel (1870), long considered a synonym of $C$. lacustris, is actually a valid species. Ploeg (1991) considered C. polysticta to be valid, apparently overlooking Lucena \& Azevedo's (1989) synonymization of $C$. polysticta with $C$. punctata.

The present paper serves to document a much greater diversity of Crenicichla species along the southeastern Brazilian coast than hitherto considered. Several of the species have very limited geographical distributions within areas that are among the most densely populated in Brazil and therefore may be considered as vulnerable.

\section{Material and Methods}

Measurements and counts follow Kullander (1986). The length of a specimen is given as the standard length (SL), unless otherwise specified, and is measured from the tip of the upper jaw to the middle of the base of the caudal fin. The principal scale count, E1 scales, includes the scales in the row immediately above the row that includes the lower lateral line. We refer to the dark horizontal stripe along the middle of the side as a lateral band. A dark stripe below the orbit, extending vertically or obliquely caudad across the cheek, is termed a suborbital stripe. Most species treated in this paper possess a pattern of minute dark marks, referred to as spots, occurring on the flanks, sides of the head, and unpaired fins.

Clearing and counterstaining follow the method of Taylor \& Van Dyke (1985). All other material is preserved in 70-75\% ethanol. Radiographies were made with a Philips MG-105 low voltage X-ray apparatus and Agfa D2 X-ray plates. Drawings were made using a drawing tube attached to a WILD M5APO stereo dissection microscope.

The lower pharyngeal tooth plate is measured as described by Barel et al. (1977). Because of the similarity between the species only one tooth plate description, that of C. maculata, is given. The local Brazilian spelling is adopted for all river and site names. Our understanding of the laguna dos Patos system follows Malabarba (1989) and includes the lagoa Mirim.

Institutional abbreviations: DBAV - Instituto de Biologia da Universidade Estadual do Rio de Janeiro, Rio de Janeiro; FMNH - Field Museum of Natural History, Chicago; MCP -
Museu de Ciências e Tecnologia, Pontifícia Universidade Católica do Rio Grande do Sul, Porto Alegre; MNRJ - Museu Nacional, Rio de Janeiro; MZUSP - Museu de Zoologia, Universidade de São Paulo, São Paulo; NRM - Swedish Museum of Natural History, Stockholm; NMW - Naturhistorisches Museum, Vienna; UFRJ - Departamento de Zoologia, Universidade Federal do Rio de Janeiro, Rio de Janeiro; USNM - National Museum of Natural History, Smithsonian Institution, Washington, D.C.

The order of the species descriptions follows geographically from north to south. Additional comparative materials examined are those listed in Lucena \& Kullander (1992).

\section{Results}

Key to the species of Crenicichla from the coastal river drainages of southeastern Brazil

1. Scales in a lateral row 57-63 (modally 61 ); 10-12 soft dorsal fin rays; a series of narrow dark vertical stripes along sides; lateral band absent; small dark spots on flanks and sides of head absent ............................... C. mucuryna (upper rio Mucuri drainage)

1'. Scales in a lateral row 56-75 (modally 65); 11-13 soft dorsal fin rays; narrow vertical stripes absent; prominent dark lateral band or horizontally arranged series of dark blotches present; numerous small dark spots present or absent on flanks and side of head

2. A series of large, partly contiguous blotches below the upper lateral line, continued as band on caudal peduncle; suborbital stripe always well developed, extending to or nearly to preopercle ........................................................... 3

2'. Series of large contiguous blotches below upper lateral line absent; dark lateral band present along middle of side from head to caudal fin, or flanks only with pattern of minute dark spots; suborbital stripe well developed, but not as above, or short . 4

3. Minute dark spots present on flanks and on side of head (occasionally absent in females); ocellated blotch present in dorsal fin in females .... C. punctata

(laguna dos Patos system)

3'. Minute dark spots absent from side of head even if side of body is richly spotted; females never with ocellated spot in dorsal fin .................................... Crenicichla maculata

(lagoa dos Quadros, Rio Grande do Sul north to rio Itapocu drainage, Santa Catarina).

4. Suborbital stripe well delevoped, extending across more than half depth of cheek C. iguapina

(rio Ribeira de Iguape system).

4'. Suborbital stripe short, restricted to orbital margin or at most extending to near middle of cheek

5. Males, and occasionally females, with dark (maroon or reddish in life) spots on side of head; body either with numerous minute dark spots (males) or with few or indistinct spots and with well marked lateral band (females) ..... C. lacustris

(rio Paraíba do Sul drainage to rio Buranhem, Bahia) 
5'. Dark or reddish spots on side of head absent in both sexes; both lateral band and spots on side of body well marked in both sexes C. tingui (rio Itapocu, Santa Catarina to rio Nhundiaquara drainage, Paraná)

\section{Crenicichla mucuryna Ihering}

Fig. 1

Crenicichla mucuryna Ihering, 1914: 335 (Type-locality: rio Todos os Santos, afluente do rio Mucury).

Material examined. 32 specimens, 33.9-113.3 mm, all from Brazil, State of Minas Gerais. MZUSP 2526 (1, $113.3 \mathrm{~mm})$, rio Todos os Santos, tributary of the rio Mucuri, mun.Teofilo Otoni, 1908, E. Garbe, lectotype of C. mucuryna; MZUSP 5385 (1, $69.9 \mathrm{~mm})$, same data as lectotype, paralectotype; MZUSP $5386(1,110.0 \mathrm{~mm})$, same data as lectotype, paralectotype; USNM $307807(1,84.0 \mathrm{~mm})$, rio Mucuri, mun. Nanuque, $17^{\circ} 50$ 'S $40^{\circ} \mathrm{W}$; USNM 318226 (28, 33.9$81.5 \mathrm{~mm}$ ), rio Mucuri about $9 \mathrm{~km} \mathrm{~W}$ of town of Presidente Pena along dirt road on Fazenda Gavião, mun. Presidente Pena, $17^{\circ} 41^{\prime} \mathrm{S} 40^{\circ} 55^{\prime} \mathrm{W}$.

Diagnosis. A small species of Crenicichla of the C. lacustris group sensu lato, not known to exceed $113 \mathrm{~mm}$, distinguished from all other coastal southeastern Brazilian species by presence of a row of 9-12 narrow vertical stripes along middle of side, most of which derived from doubling or tripling of vertical bars descending from dorsum $v$ s. absence of narrow vertical stripes; absence of pattern of small dark scattered spots on side of body, vs. presence. Similar in low scale counts (E1 53-63) and color patter (narrow vertical stripes) to species of C. lacustris group from upper rio Paraná basin, viz. C. haroldoi (E1 scales 50-56) and C. jaguarensis (E1 scales 47-53), both distinguished by a long, wide suborbital stripe and a lateral band more prominent than vertical bars; $C$. jupiaensis (E1 scales 49-55) with narrow vertical bars extending all the way from dorsal-fin base to abdominal side, suborbital stripe modified into a group of spots, and caudal spot expressed as a vertical bar; and C. niederleinii (E1 scales 57-65), with narrow, but long suborbital stripe, and well-marked lateral band. From C. iguassuensis, C. mucuryna can be distinguished by color pattern (absence vs. presence of scattered dark spots on side, and presence $v s$. absence of narrow vertical stripes).
Description. Based primarily on specimens over $50 \mathrm{~mm}$. Largest male $113.3 \mathrm{~mm}$, largest female $65.4 \mathrm{~mm}$. Measurements given in Table 1, counts in Tables 4-8. See Fig. 1 for general aspect.

Comparatively elongate, body depth $16.3-22.5 \%$ SL. Head as deep as wide. Caudal peduncle longer than deep. Snout moderately long, rounded when viewed from above, moderately pointed in lateral view. Lower jaw slightly prognathous. Ascending premaxillary process reaching to or almost to $1 / 3$ of orbit. Maxilla reaching to vertical from anterior margin of orbit. Upper lip thick and wide, folds not continuous but cutting into symphyseal wide thickening. Postlabial skin fold margin truncate. Orbit supralateral, not visible from below, chiefly in anterior half of head. Nostrils dorsolateral, about halfway between orbit and margin of postlabial skin fold and with low tubular margin but no anterior marginal skin flap. Vertical margin of preopercle smooth or with few irregularly distributed projections.

Flank scales strongly ctenoid. All scales on head, anteriorly on back (above about anterior $1 / 4$ of lateral line), along dorsal fin base, chest, and on belly below line from lower edge of pectoral axilla to anal fin origin and along anal fin base cycloid. Predorsal scales small, superficially embedded in skin, extending forward almost to transverse frontal lateralis canal. Prepelvic scales very small, superficially embedded in skin. Cheek fully scaled or narrowly naked ventrally and anteroventrally; 6-9 scale rows below eye, embedded in skin. Interopercle naked. Circumpeduncular scale rows 10-12 dorsally, 10-14 ventrally (total 22-25 including lateral lines).

Scales between upper lateral line and dorsal fin base 8-11 anteriorly, 4 posteriorly; 3 scale rows between lateral lines. Anterior upper lateral line scales slightly larger and more elongate than adjacent scales, remaining lateral line scales nearly the same size as adjacent scales; three scales impinging on each scale of anterior part, two on each scale of posterior part of upper lateral line; 2 scales impinging on each scale of lower lateral line. Dorsal, anal, pectoral, and pelvic fins without scales. Caudal fin squamation concave, marginally extending to near middle of fin.

First dorsal spine about 1/3-1/4 length of last; spines increasing in length to last but subequal from about 10th. Soft part of dorsal fin pointed in males, rounded in females, 7 th-

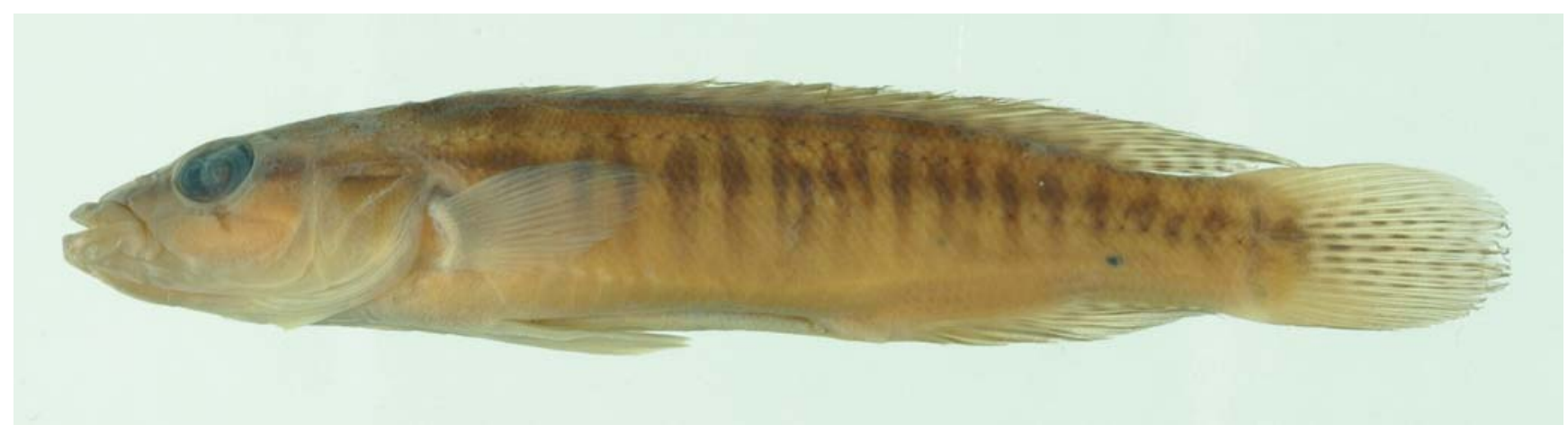

Fig. 1. Crenicichla mucuryna, USNM 307807, $84.0 \mathrm{~mm}$ SL, rio Mucuri, Nanuque, State of Minas Gerais, Brazil. 
Table 1. Morphometry of Crenicichla lacustris and C. mucuryna. $\mathrm{n}=$ number of specimens; $\mathrm{SD}=\mathrm{Standard}$ deviation.

\begin{tabular}{|c|c|c|c|c|c|c|c|c|c|c|}
\hline \multirow[b]{3}{*}{ Measurement } & \multicolumn{4}{|c|}{ C. lacustris } & \multicolumn{5}{|c|}{ C. mисигуna } & \multirow[b]{3}{*}{ SD } \\
\hline & \multicolumn{4}{|c|}{ Range } & \multicolumn{5}{|c|}{ Range } & \\
\hline & $\mathrm{n}$ & Min & $\operatorname{Max}$ & Mean & SD & $\mathrm{n}$ & Min & $\operatorname{Max}$ & Mean & \\
\hline Standard length $(\mathrm{mm})$ & 51 & 70.3 & 233.2 & 132.8 & & 18 & 60.4 & 113.3 & 75.6 & \\
\hline \multicolumn{11}{|c|}{ Percents of standard length } \\
\hline Body depth & 50 & 18.6 & 23.9 & 21.2 & 1.238 & 18 & 16.3 & 22.5 & 20.3 & 1.645 \\
\hline Caudal peduncle length & 51 & 12.7 & 17.2 & 15.4 & 0.902 & 18 & 13.6 & 17.2 & 15.1 & 0.893 \\
\hline Caudal peduncle depth & 51 & 9.7 & 11.7 & 10.6 & 0.497 & 18 & 9.8 & 11.6 & 10.6 & 0.442 \\
\hline Last D spine length & 45 & 9.1 & 12.5 & 10.5 & 0.848 & 18 & 10.5 & 14.1 & 12.6 & 0.993 \\
\hline Pectoral fin length & 50 & 13.5 & 20.5 & 17.4 & 1.595 & 18 & 16.9 & 20.9 & 19.1 & 1.183 \\
\hline Head length & 51 & 29.1 & 36.0 & 31.7 & 1.439 & 18 & 27.5 & 32.3 & 31.0 & 1.048 \\
\hline Head depth & 51 & 12.0 & 16.9 & 14.2 & 1.109 & 18 & 11.7 & 15.4 & 14.2 & 0.805 \\
\hline Snout length & 51 & 8.3 & 12.8 & 10.8 & 0.933 & 18 & 8.9 & 10.4 & 9.7 & 0.471 \\
\hline Orbital diameter & 51 & 4.6 & 8.8 & 6.5 & 0.998 & 18 & 6.1 & 8.8 & 7.5 & 0.621 \\
\hline Interorbital width & 51 & 4.4 & 8.6 & 6.1 & 0.968 & 18 & 4.9 & 6.5 & 5.6 & 0.447 \\
\hline Upper jaw length & 51 & 10.1 & 14.8 & 12.1 & 1.169 & 18 & 9.3 & 20.5 & 11.3 & 2.389 \\
\hline Lower jaw length & 51 & 14.2 & 19.1 & 16.2 & 1.351 & 18 & 13.0 & 16.7 & 14.5 & 0.925 \\
\hline
\end{tabular}

8th rays reaching slightly beyond base of caudal fin. Soft anal fin with rounded tip, in both sexes reaching to base of caudal fin. Caudal fin rounded. Pectoral fin rounded, reaching about halfway to anal fin. Pelvic fin inserted well posterior to vertical from pectoral axilla, with acuminate tip, second ray longest, reaching about halfway to spinous anal fin or slightly beyond; anterior margin slightly thickened.

All teeth pointed, erect or slightly recurved. Outer row of teeth distinctly larger than inner teeth and larger anteriorly than posteriorly. Upper jaw with 4-5 inner rows; outer row teeth slightly movable or fixed, inner teeth fully depressible. Lower jaw anteriorly with 3 inner rows; all teeth inclinable or depressible.

Microbranchiospines very small, easily overlooked, but present externally on 2nd-4th arches.

Coloration in alcohol. Lateral line scales light with dark brown dot distally. Neither males nor females with small dark spots on sides as in other coastal Crenicichla species. Dark brown preorbital stripe from orbit running anteriorly and crossong lips to lower jaw. Dark brown postorbital stripe straight from orbit to dorsal end of opercle. Nuchal markings include blackish spot little above posttemporal and dark stripe along margin of predorsal squamation above sphenotic. Suborbital stripe black, very narrow, and short, crossing only 2-3 scale rows.

Both sexes with six wide brown bars or blotches between dorsal fin base and upper lateral line; first blotch contiguous with brownish blotch below upper lateral line, remaining blotches each transforming into 2-3 narrow dark brown vertical stripes, most intense between levels of lateral lines. Another dark bar across dorsal margin of caudal peduncle, not split like preceding vertical markings. In larger males, however, dark markings on caudal peduncle separated into smaller dark spots. Narrow vertical stripes number varies between 9 and 12 .

Dorsal fin in males grayish with 2-3 rows of small dark brown spots. Caudal fin with small brown, light-ringed spot between rays D1-D3, and 6-7 vertical rows of small dark spots, most intense along middle rays. Anal fin grayish, with about 3 rows of dark spots posteriorly. In females, unpaired fins usually immaculate save for ocellar blotches, but three specimens (56.9-61.8 $\mathrm{mm}$ ) have few dark spots on caudal fin, in one also on dorsal fin. In these females no dorsal ocellus present or fin only slightly darker in its place. Dorsal fin ocellus present in 8 females (52.7-65.8 mm) between rays 12-16, 12-17, 13-15, 13-18 (usually 13-17), deep black, ocellation varying from hyaline dorsal margin to complete hyaline ring. Caudal fin in females usually with middle portion darker than rest and caudal spot without light ring. Pelvic fins without pigmentation in both sexes.

Two juveniles, 33.9-39.5 mm, similar to adults in body and fin coloration, i.e. with vertical bars across sides and spotted fins.

Geographical distribution. Known only from three localities in the rio Mucuri drainage, in the upper rio Todos os Santos at Teofilo Otoni, in the rio Mucuri close to the mouth of the rio Todos os Santos, and at Nanuque (Fig. 2).

Habitat. USNM 318226 was taken in a side branch of the main river with some rapids, to $1.25 \mathrm{~m}$ deep, the bottom sandy, with boulders. The surroundings were pasture with remnants of gallery forest and scattered inga trees.

Notes. Crenicichla mucuryna is different in overall morphology and color pattern from all coastal species of Crenicichla treated in this paper. It completely lacks the pattern of small dark spots covering the body and often the side of the head in one or both sexes that characterize the remaining coastal species. Instead it has a conspicuous pattern of narrow dark vertical bars across the middle sides, and males have an irregular pattern of dark blotches on the caudal peduncle. The barred pattern resembles that of species of Crenicichla from the upper Paraná drainage. Among those species, $C$. jupiaensis is notable for its numerous narrow vertical bars extending all the way from the dorsal fin base to the lower side. Crenicichla jaguarensis, C. haroldoi, and C. niederleinii have a distinct lateral band, but also narrow vertical bars crossing it. Like C. mucuryna, Paraná species have fairly low 
scale counts, E1 row scales ranging from 47-65, contrasting with the other species of the C. lacustris group (63-70, rarely fewer than 60). The sexual dimorphism is similar to that reported for $C$. missioneira and related species, in which males have a spotted caudal peduncle, but not females (Lucena \& Kullander, 1992). However, in C. mucuryna, the irregular spots on the caudal peduncle represent homologues of the more anterior vertical bars.

Further comparison of $C$. mucuryna with the remaining coastal species of the C. lacustris group seems unwarranted, but the species should be reconsidered in a revision of the barred Crenicichla species from the Paraná drainage. The pattern of narrow bars may provisionally be taken as a synapomorphy, although vertical bars occur in a larger group of Crenicichla. It is notable that C. mucuryna only occurs in the upper rio Mucuri and is not syntopic with other species of Crenicichla. We believe that the upper Mucuri may represent an old part of the Paraná drainage, which was diverted to an Atlantic drainage and has remained isolated, but we are unable to propose a detailed historical scenario, especially since the Mucuri now is margined by coastal drainages with only species of the C. lacustris group, and the São Francisco drainage which has only species of the C. lepidota group. A large number of non-cichlid species were collected in association with $C$. mucuryna that seem for the most part to represent common coastal taxa at species or genus level.

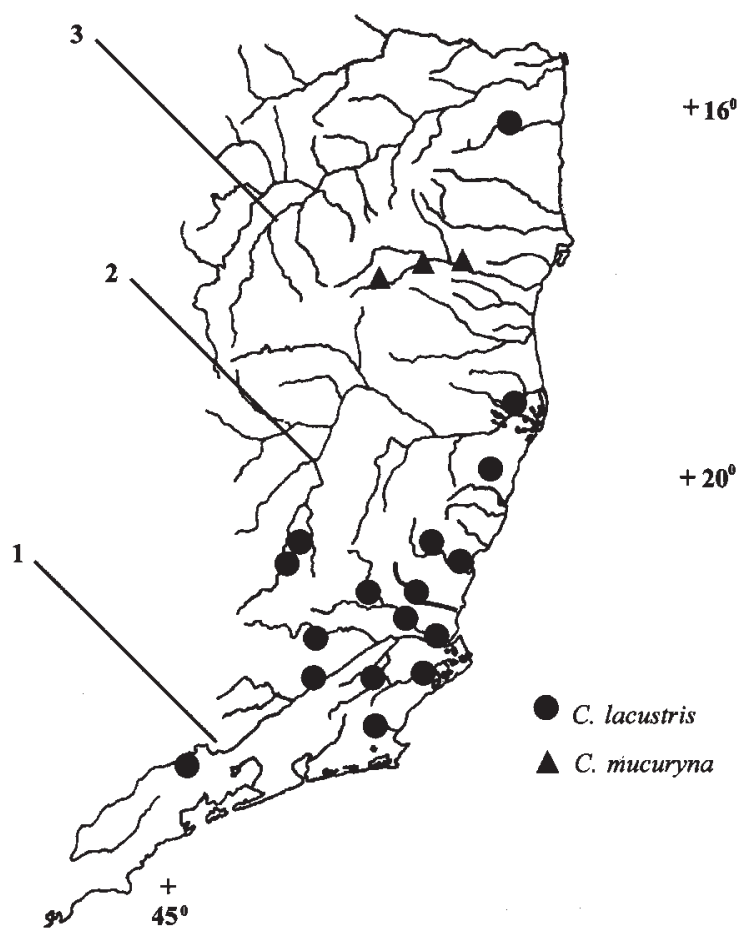

Fig. 2. Collecting localities of Crenicichla lacustris and $C$. mucuryna in the coastal rivers of eastern Brazil. Most important rivers are: 1. Rio Paraíba do Sul; 2. Rio Doce; and 3. Rio Jequitinhonha. A symbol may cover more than one collecting site.

\section{Crenicichla lacustris (Castelnau)}

Figs. 3-4

Cycla lacustris Castelnau, 1855: 19, pl. 8 fig. 3 (Type-locality: Dique, ou étang près de Bahia).

Crenicichla dorsocellata Haseman 1911: 355, pl. 63 (Typelocality: Campos, R. Parahyba).

Crenicichla biocellata von Ihering, 1914: 333 (Type-locality: Rio Doce, Espírito Santo).

Material examined. 164 specimens, 54.2-290 mm, all from Brazil. Bahia: Syntype of C. lacustris, MNHN A9501 (1 of 2, $126.0 \mathrm{~mm}$ ), dique, ou étang près de Bahia. USNM $318218(2,75.0-171 \mathrm{~mm})$, rio Buranhem, approx. 5-6 km SSE of Eunápolis, Eunápolis, ca. $16^{\circ} 25^{\prime} \mathrm{S}$ $39^{\circ} 35^{\prime} \mathrm{W}$. Minas Gerais: rio Doce drainage (all the rio Doce lakes are between $19^{\circ} 35^{\prime}-19^{\circ} 55^{\prime} \mathrm{S}, 42^{\circ} 25^{\prime} 42^{\circ} 40^{\prime} \mathrm{W}$. Lagoa Dom Helvécio is the largest, at $19^{\circ} 46^{\prime} \mathrm{S} 42^{\circ} 37^{\prime} \mathrm{W}$, near the left bank of the upper rio Doce, slightly east of the city of Marlieria): Lagoa Dom Helvécio: DBAV 0072 ( 1, $172.6 \mathrm{~mm})$; DBAV 0073 (1, $121.7 \mathrm{~mm})$; DBAV 0426 (7, 54.2-220.0 mm); DBAV 0548 (2, 210.0-235.0 mm); DBAV 1147 (2, 112.0-130.2 mm); DBAV 1148 (2, 125.0-138.6 mm); DBAV 1149 (3, 99.3-206.0 mm); DBAV 1150 (2, 197.0-206.3 mm); DBAV 1151 (2, 198.0-233.2 mm); DBAV 1152 (1, 117.2 mm); DBAV 1153 $(1,141.5 \mathrm{~mm})$; DBAV $1157(1,126.0 \mathrm{~mm})$; DBAV $1158(4,118.4$ $133.7 \mathrm{~mm}$ ) ; DBAV 1159 (3, 101.5-133.9 mm); DBAV 1161 ( 4, 116.0-163.0 mm); DBAV 1162 (2, 127.8-163.6 mm); DBAV 1163 (2, 127.6-138.4 mm); DBAV 1164 (2, 139.8-144.8 mm); DBAV 1165 (1, $162.0 \mathrm{~mm})$; DBAV 1166 (7, 111.5-119.7 mm); and DBAV 1167 (2, 115.5-124.7 mm); DBAV 1168 (3, 102.4-135.0 mm). Lagoa Carioca: DBAV 0637 (1, $114.4 \mathrm{~mm})$; DBAV 0642 (2, 87.7-119.7 $\mathrm{mm})$; DBAV 1154 (1, $119.2 \mathrm{~mm})$; DBAV 1155 (3, 87.5-122.8 mm); DBAV 1156 (7, 96.6-115.0 mm); DBAV 1160 (1, $122.9 \mathrm{~mm})$; DBAV 1169 (3, 119.0-132.8 mm); DBAV 1170 (3, 56.7-86.7 mm); DBAV 1171 (2, 80.0-94.7mm); and DBAV 1172 (2, 96.4-98.0 mm). Rio Paraíba do Sul drainage: MNRJ 14390 (4, 84.8-114.6 mm), rio Novo, $6 \mathrm{~km}$ above of the confluence with rio Pomba, approx. $21^{\circ} 24^{\prime} \mathrm{S}$ 4246'W; UFRJ 3731 (1, 144.8 mm), rio Paraíba do Sul, Além Paraíba, 21 ${ }^{\circ} 53$ 'S 4240’30"W. Espírito Santo: MCP 18242 (4, 59.3-89.0 $\mathrm{mm}$ ), rio Itabapoana, Bom Jesus do Itabapoana; MCP 18143 (2, 21.9-74.7 mm), rio São José das Torres on the road BR 101, between

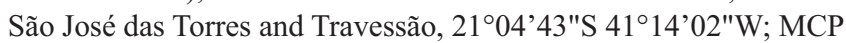
$18144(6,14.4-98.4 \mathrm{~mm})$, rio Novo do Sul (tributary of rio Moa) on the road BR-101 just to the south of Rio Novo, rio Itapemirim drainage, 2052'33"S 4057'50"W; MNRJ 5274 (2, 78.0-105.3 mm), lagoa Juparanã, rio Doce drainage, road Linhares-São Mateus, mun. Linhares, ca. $19^{\circ} 19^{\prime} \mathrm{S} 40^{\circ} 05^{\prime} \mathrm{W}$; holotype of C. biocellata, MZUSP 1167 (1, $215.0 \mathrm{~mm}$ total length), lower rio Doce; paratype of $C$. biocellata, MZUSP $1781(1,150.0 \mathrm{~mm})$, rio Santa Maria da Vitória, Santa Leopoldina, ca 2006’30" 40³2'W; MZUSP 27570 (1, 96.8 $\mathrm{mm})$, rio São José das Torres, road BR-101 Campos-Cachoeiro do Itapemirim. Rio de Janeiro: DBAV 095 (1, $108.0 \mathrm{~mm})$, rio Paraíba do Sul drainage, near Resende, ca. $22^{\circ} 28^{\prime}$ 'S 442ㄱ'W; DBAV 096 (1, $101.0 \mathrm{~mm})$, same locality; DBAV $0101(1,76.7 \mathrm{~mm})$, represa do Funil, ca. 22 33 'S 443' 'W; DBAV 0247 (2, 71.0-124.6 mm), near Resende, ca. $22^{\circ} 28^{\prime}$ 'S 4427'W; DBAV 0854 (1, 290.0 mm), rio São João, Silva Jardim; DBAV 1173 (2, 116.9-134.3 mm), rio Pirapitinga, Resende, $22^{\circ} 40^{\prime} \mathrm{S} 42^{\circ} 23^{\prime} \mathrm{W}$; holotype of Crenicichla dorsocellata, FMNH 54155 (1, $177.0 \mathrm{~mm}$ ) (previously CM 2721), rio Paraíba do Sul, Campos, ca. 2146'S 41¹9'20"W; MNRJ 13394 (11, 61.1$149.9 \mathrm{~mm})$, lagoa Brejo Grande, Campos; MNRJ 14391 (1, 143.3 $\mathrm{mm})$, lagoa Feia, Macaé, ca. $22^{\circ} \mathrm{S} 41^{\circ} 22 \mathrm{~W}$; MNRJ 14392 (1, 124.8 


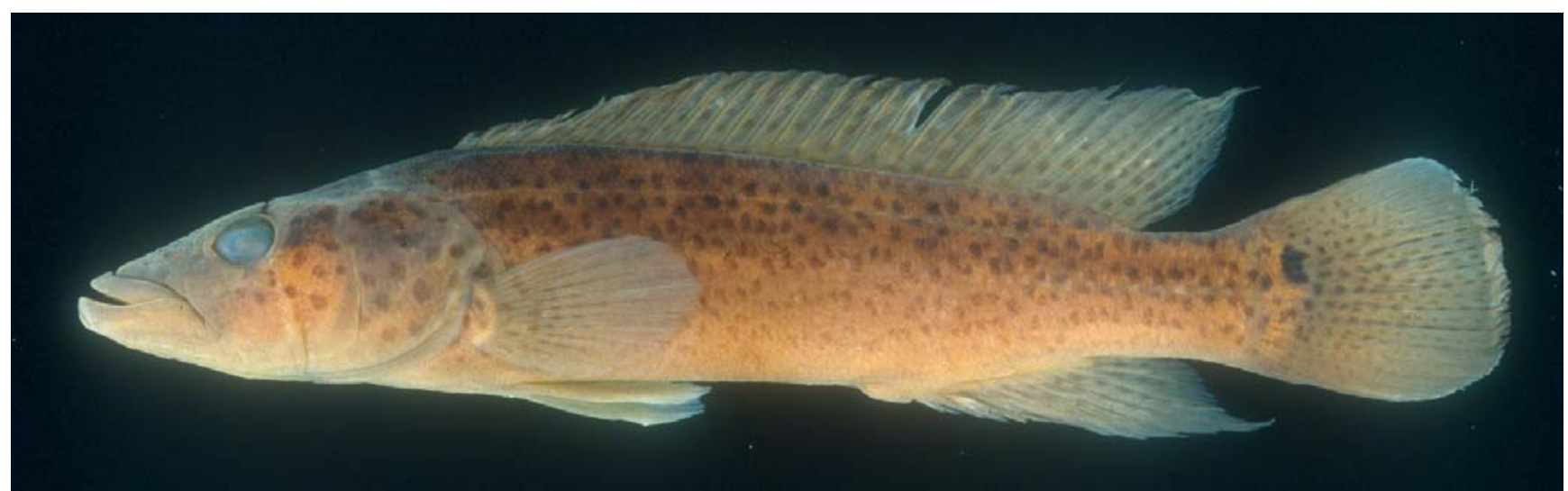

Fig. 3. Crenicichla lacustris, male, MNRJ 14394, 173.7 mm SL, ribeirão São Domingos, rio Muriaé drainage, State of Rio de Janeiro, Brazil.

$\mathrm{mm}$ ), stream on road BR-393, $10 \mathrm{~km}$ from Monte Alegre, mun. Santo Antônio de Pádua; MNRJ 14393 (1, 157.5 mm), valão do rio São Domingos, at São José de Uloa, $21^{\circ} 21^{\prime} \mathrm{S} 41^{\circ} 57^{\prime} \mathrm{W}$, Itaperuna, rio Muriaé system; MNRJ 14394 (6, 91.3-173.7 mm), ribeirão São Domingos, at São José de Uloa, $21^{\circ} 21^{\prime} \mathrm{S} 41^{\circ} 57^{\prime} \mathrm{W}$, rio Muriaé system, Itaperuna; MNRJ 14395 (8, 4 measured, 162.7-222.4 mm), represa do Funil, Resende, ca 22³3'S 44³5'W; MNRJ 14396 (7, 18.9-37.3 mm), rio Carangola, left bank tributary of rio Muriaé at Bridge on road BR 356, Itaperuna, ca. $21^{\circ} 12^{\prime}$ 'S $41^{\circ} 55^{\prime} \mathrm{W}$; MNRJ 14397 (1, 125.7 mm), córrego Romão, Romão, km 2 on road BR-393, Cambuci, ca. 2133'30"S 41 $55^{\prime}$ 'W; MNRJ 14398 (1, 123.6 mm), rio Pirapitinga, Resende, 3 or $4 \mathrm{~km}$ from the mouth, Monte Alegre; MNRJ 14399 (1, $190.1 \mathrm{~mm})$, lagoa de Cima, ca. 21²4'28"S 4131'40"W; MZUSP 3150 (1, $101.3 \mathrm{~mm}$ ), rio Muriaé, Cardoso

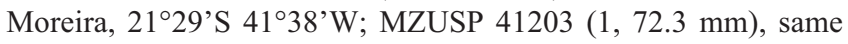
data; MZUSP 41215 (2, 96.8-120.8 mm), rio Paraíba do Sul, São João da Barra, ca. 21 ${ }^{\circ} 38^{\prime}$ 'S 41 ${ }^{\circ} 03$ '30"W; MZUSP 41216 (1, 117.8 $\mathrm{mm}$ ), córrego Pedra D’água, São Fidélis, 21³9’20"S 4145’40"W; UFRJ 3733 (2, 113.3-224.0 mm), UFRJ 3736 (1, $113.7 \mathrm{~mm}$ ), and UFRJ 3737 (1, $158.0 \mathrm{~mm})$, rio Muriaé, left bank tributary to rio Paraíba do Sul, near crossing of roads BR 356 and RJ-186, Itaperuna, 2112’30"S 41 53'30"W; UFRJ 3740 (1, 111.9 mm), rio Grande, source of rio Dois Rios (right bank tributary of rio Paraíba do Sul), 2 km from bridge of road RJ-172, fazenda Humaita, São Sebastião do Alto, ca. $22^{\circ} 01^{\prime} \mathrm{S} 42^{\circ} 08^{\prime} \mathrm{W}$; UFRJ 3744 (2, 90.0-100.2 mm), rio Dois Rios, right bank tributary to rio Paraíba do Sul, fazenda Poço d'Antas, São Fidélis.
Diagnosis. An elongate, large sized species of the $C$. lacustris group, distinguished from all other coastal southeastern Brazilian species by its color pattern. Lateral band continuous from head to caudal fin base, vs. subdivided into a series of blotches in C. punctata and C. maculata; suborbital stripe short and narrow, occasionally obsolete, vs. wide and prominent in C. iguapina; small dark spots on side of head present, $v s$. absent in $C$. tingui; in $C$. tingui both males and females have side of body spotted, though in males spots not extending onto abdominal side and lateral band remaining prominently pigmented, whereas in C. lacustris males lateral band indistinct in combination with dark spot pattern. From other species of the $C$. lacustris group, $C$. lacustris can be distinguinshed by E1 row scales count, 60-75 (vs. 47-65) and presence (vs. absent) of small dark spots on side of head present.

Description. Based primarily on specimens over $100.0 \mathrm{~mm}$. Largest male $235.0 \mathrm{~mm}$, largest female $290.0 \mathrm{~mm}$. Measurements given in Table 1, counts in Tables 4-8. See Figs. 3-4 for general aspect.

Comparatively elongate, body depth 18.6-23.9\% SL. Head about as deep as wide or slightly deeper than wide. Caudal peduncle longer than deep. Snout long, rounded when viewed from above, pointed in lateral view. Lower jaw prognathous.

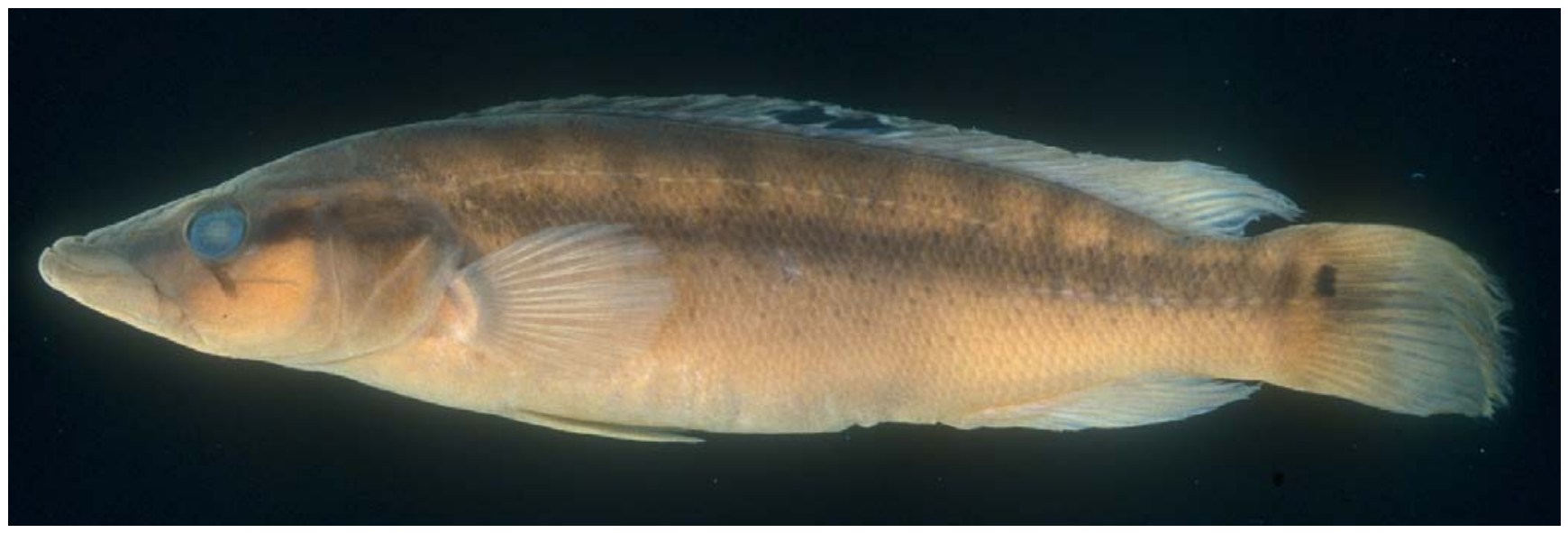

Fig. 4. Crenicichla lacustris, female, USNM 318218, 171.0 mm SL, rio Buranhem, State of Bahia, Brazil. 
Ascending premaxillary process reaching to $1 / 2$ of orbit. Maxilla reaching to vertical from anterior margin of orbit. Upper lip thick and wide, folds not continuous but cutting into symphyseal wide thickening. Postlabial skin fold margin truncate or slightly rounded. Orbit supralateral, not visible from below, chiefly in anterior half of head. Nostrils dorsolateral, about halfway between orbit and margin of postlabial skin fold and with low tubular margin but no anterior marginal skin flap. Preopercle regularly serrated.

Flank scales strongly ctenoid. All scales on head, anteriorly on back, along dorsal fin base, chest, and on belly below line from lower edge of pectoral axilla to anal fin origin and along anal fin base cycloid. Predorsal scales small, superficially embedded in skin, extending forward almost to transverse frontal lateralis canal. Prepelvic scales very small, superficially embedded in skin. Cheek fully scaled or narrowly naked ventrally and anteroventrally; 7-11 rows of scales below eye, embedded in skin. Interopercle naked. Circumpeduncular scale rows 11-15 dorsally, 12-16 ventrally (total 2833, including lateral lines).

Scales between upper lateral line and dorsal fin base 9-12 anteriorly, 4-6 posteriorly; 3-4 scale rows between lateral lines. Anterior upper lateral line scales slightly larger and more elongate than adjacent scales, remaining lateral line scales nearly same size as adjacent scales; 3 scales impinging on each scale of anterior part, 2 on each scale of posterior part of upper lateral line; 2 scales impinging on each scale of lower lateral line. Scales absent from dorsal, anal, pectoral, and pelvic fins. Caudal fin squamation concave, marginally extending beyond middle of fin.

First dorsal spine about 1/3-1/4 length of last; spines increasing in length to last but subequal from about $10^{\text {th }}$. Soft part of dorsal fin pointed; both sexes sometimes with produced middle rays, reaching to about base of caudal fin. Soft anal fin with acuminate tip; not reaching to caudal fin base in both sexes. Caudal fin rounded. Pectoral fin rounded, reaching about halfway to anal fin origin. Pelvic fin inserted well posterior to vertical from pectoral axilla, with acuminate tip, second ray longest, reaching about halfway to anal fin origin; anterior rays and margin thickened.

All teeth pointed, slightly recurved. Outer row of teeth distinctly larger than inner teeth and larger anteriorly than posteriorly. Upper jaw with 4-5 inner rows; all teeth depressible. Lower jaw anteriorly with 3 inner rows; all teeth inclinable or depressible.

Microbranchiospines present externally on second through fourth gill arches.

Coloration in alcohol. Yellowish to brownish, darker on back, whitish on belly, with brown or black markings. Lateral line scales light. Upper lip gray. Dark brown preorbital stripe from orbit to margin of mouth. Dark brown postorbital stripe runnning straight from orbit to dorsal end of gill cleft, sometimes reduced to blackish spot immediately posterior to orbit. Nuchal markings very light in medium and large specimens. In specimens up to $116 \mathrm{~mm}$ (MNRJ 13394) sometimes with black blotch along posttemporal and dark band along margin of predorsal scales above sphenotic.

Suborbital stripe black, never extending below middle of cheek, and sometimes reduced to small spot at orbital margin. Occasionally ends in few dots scattered down cheek for three or four scales. Suborbital stripe better developed in females than in males. Males with body covered with seemingly irregularly scattered blackish spots, except for ventral part of abdomen. Such spots found also on opercle and subopercle and posteriorly on cheek. Small specimens (to ca. $75 \mathrm{~mm}$ ), however, lack spots on head. Females have spots on body or completely lack body spots. Both sexes with wide horizontal dark stripe extending from gill opening to end of caudal peduncle, restricted to area between lateral lines, but generally more distinct in females. Females also generally show 5-7 well expressed vertical bars extending from lateral band to dorsal fin base, and another two dark blotches across dorsal margin of caudal peduncle.

Dorsal fin in females smoky with wide dark margin and sometimes with distinct light submarginal stripe. Most females with slightly elongate, ocellated black blotch with white margin on middle portion of dorsal fin, usually between $13^{\text {th }}$ and $17^{\text {th }}$ or $12^{\text {th }}$ and $17^{\text {th }}$ spines; one female (USNM 318218 ) show ocellus between $11^{\text {th }}$ and $14^{\text {th }}$ spines and another small one between $14^{\text {th }}$ and $17^{\text {th }}$, in small females blotch sometimes indistinct and without clearly defined light margin. Soft portion of dorsal fin may feature few dark dots. Males with dorsal fin grayish with numerous dark spots irregularly distributed over both spinous and soft portions.

Anal fin grayish; males with numerous dark spots on posterior membranes; in females anal fin immaculate or with only few dark spots. Pelvic fins whitish. Females with only few dark spots on caudal fin. Caudal fin of males vividly patterned with dark dots. Rounded caudal spot black and ocellated. One male specimen (MNRJ 14394) with dark dots between pectoral fin rays, otherwise pectoral fin immaculate.

Color in life. Two large adults, male and female, ca. 220 and $230 \mathrm{~mm}$, from lagoa de Juturnaiba, State of Rio de Janeiro, collected July 1981 and photographed freshly preserved, similar to preserved specimens. However, dark spots on side and head maroon, more reddish in male, and female with orange horizontal stripe along side of abdomen adjacent to lateral band. Lateral band conspicuous in both specimens. Young female from rio do Salto, Macaé, State of Rio de Janeiro, collected 28 January 1997 also with well marked lateral band and many large reddish spots on sides and gill cover.

Variation. Data is given separately here for the sample from the rio Doce lakes. These specimens are in a poor state of preservation and the only two specimens sexed are definitely females. These specimens differ from other $C$. lacustris in having a longer snout, a more prognathous (and longer) lower jaw, and a modal anal fin count of III,8 rather than III,9. None of the specimens features a lateral band, as is always evident in female $C$. lacustris from elsewhere and commonly also apparent 
at least as a trace in males. Instead both sexes have spots all over the body, the females also featuring dark spots on the gill cover. Although Menezes (1987) was able to distinguish the sympatric rio Doce Oligosarcus as a species distinct from the species of Oligosarcus in the Paraíba do Sul and coastal plain, we hesitate to give species status to the rio Doce Crenicichla for want of well preserved material that would enable us to provide a useful diagnosis. With the material at hand, the overlap of counts and meristics prevents us from a satisfactory diagnosis, and the state of preservation makes a proper evaluation of the color pattern equally unsatisfactory.

Stomach contents. Two stomachs examined, DBAV 0426 (154.2 $\mathrm{mm}$ ) and MNRJ 14390 (84.8 mm), contain fish remains.

Geographical distribution. Collections range from coastal rivers from rio Buranhem south to rio Paraíba do Sul, including the rio São João drainage in the State of Rio de Janeiro (Fig. 2). There is one population in the lakes of the upper rio Doce, but otherwise no material is available from the upper rio Doce valley. The species apparently occurs all along the rio Paraíba do Sul downstream from the area of Resende. The species is absent from the rio Mucuri, which is within the total range of C. lacustris.

Notes. The two syntypes of $C$. lacustris were reported by Castelnau to come from Bahia (= Salvador, State of Bahia). As no Crenicichla lacustris group species has been found again further north than the rio Buranhem, we find it likely that the locality given by Castelnau is in error. Castelnau lived in Salvador as the French Consul in 1849 and wrote the multivolume itinerary of his South American travels in that period (Papavero, 1975). Circumstantial evidence suggests, however, that no C. lacustris group species occur in the Salvador area, and that the syntypes of $C$. lacustris most likely came from near Rio de Janeiro where Castelnau stayed from 17 June till 13 October 1843.

Recent extensive collecting efforts in the rio Jequitinhonha and rivers from the Jequitinhonha north to include the rio Paraguaçu (by J. Garavello, S. Jewett and R. Macedo, and R. E. Reis et al.) failed to locate any Crenicichla material. The Buranhem specimens (the next river south from the Jequitinhonha south) reported herein likely are the most northern Crenicichla treated here, and they conform to C. lacustris.

Castelnau made his most important collecting trip in South America in 1843, starting from Rio Janeiro, travelling along the Tocantins, then west to Peru and finally down the Amazon and through to Guyana from where he returned to France in 1847.

Castelnau (1855) reported mostly on marine fishes observed or collected at Salvador and Rio de Janeiro, and freshwater fishes mostly collected or observed in the Araguaia and in Peru, and in inland Minas Gerais. One species is explicitly reported from Rio de Janeiro, viz. Loricaria castanea (p. 46, currently in the genus Loricariichthys). Erythrinus trahira (presumably an Hoplias species) is reported as common in the fresh waters around Salvador (p. 56), Chromys paraguassu and $C$. obscura, representing a single valid species of Geophagus, are described from the rio Paraguaçu, which has its mouth at Salvador. Chalceus devillei (p. 69; now in the genus Brycon) and Tetragonopterus vittatus (p. 66) are described as new species from Bahia, and Xiphorhynchus hepseticus Müller \& Troschel is reported (p. 75) from Bahia.

Howes (1982) redescribed Brycon devillei, emphasizing the distinctiveness of the species. Howes tentatively included material from the rio Jequitinhonha (Brycon insignis Steindachner) and rio Doce. Another species described from 'Bahia', viz. B. bahiensis Günther, is apparently known only from the type specimen and one other more specimen from Rio de Janeiro (Howes, 1982). Lima (2003) assigned it as a synonym of Brycon opalinus (Cuvier), a species with the type locality Rio de Janeiro. Howes (1982) grouped B. devillei with $B$. acuminatus, B. ferox, and B. reinhardti.

Brycon ferox Steindachner is known only from the type material collected in the rio Mucuri. Howes (1982) thought that it might be the same as Brycon acuminatus (Eigenmann $\&$ Norris) (synonym of B. insignis Steindachner in Lima, 2003), known only from two specimens, both collected in the rio Tietê, a tributary of the Paraná (but the type locality was erroneous, the holotype apparently being collected in the rio Paraíba do Sul, see Howes, 1982 and Lima, 2003).

According to Lima (2003) Brycon reinhardti Lütken occurs in the São Francisco (rio das Velhas) and is assigned as a synonym of $B$. nattereri Günther (Paraná river basin).

Tetragonopterus vittatus is an Astyanax bimaculatus-like species, treated as a subspecies of $A$. bimaculatus by Fowler (1948) and later a provisional synonym of that species by Lima et al. (2003). It was reported from many localities near Salvador by Eigenmann (1921).

Menezes (1987) included Castelnau's Xiphorhynchus hepseticus in his Oligosarcus acutirostris, which was reported from many localities between the mouth of the rio Jequitinhonha south to the rio São José das Torres, State of Espírito Santo, where it is replaced by $O$. hepsetus, which ranges all the way to the rio Cubatão in Santa Catarina.

Whereas from the above there is little doubt that Castelnau had freshwater fish collections from Bahia (better understood as the present city of Salvador than as the "State of Bahia"), viz. specimens of Geophagus, Brycon devillei, and Astyanax vittatus, it is equally clear that he had freshwater fish collections from Rio de Janeiro (Loricariichthys castaneus).

We find it likely that the ' $X$. hepseticus' did not come from Salvador since there are no Oligosarcus north of the Jequitinhonha. Indeed, given that Castelnau had collections from Rio de Janeiro, it may have come from there rather than from Bahia, and represent $O$. hepsetus rather than $O$. acutirostris. Menezes did not examine Castelnau's specimens and may have relied entirely on the locality for the identification.

It is therefore possible that the Crenicichla lacustris came from somewhere near Rio de Janeiro. There is no indication or evidence known to us that Castelnau sampled along the coast between Rio de Janeiro and Bahia.

Crenicichla dorsocellata is based on the holotype from 
Campos and a paratype from Santarém, in the Amazon drainage. The latter has since been identified by most authors as a member of the $C$. wallacii group which is common in the Amazon basin, and also features a prominent dorsal fin ocellus. Crenicichla dorsocellata falls within the variation of $C$. lacustris as here understood, and is therefore synonymized with that species.

Crenicichla biocellata was described from two specimens, one from rio Doce, collected by E. Garbe in 1906 and expressly referred to as the type; the other specimen was from Porto Cachoeiro, collected by E. Garbe in 1912. The type material of C. biocellata was not listed by Miranda Ribeiro (1918) in his catalogue of fishes in the Museu Paulista (presently MZUSP). Britski (1969: 210) listed the paratype (MZUSP 1781), noting that Pôrto Cachoeiro had meanwhile changed its name to Santa Leopoldina and is situated on the rio Santa Maria da Vitória and not on the rio Doce as stated in the original description. Ploeg (1991) also listed this paratype, but as the holotype. Actually, the holotype was present in the MZUSP but went undetected until we were able to identify it with the help of O. Oyakawa as a specimen of $215 \mathrm{~mm}$ total length in a lot of two specimens (MZUSP 1167), with collecting data as the lower rio Doce, E. Garbe 1906. The specimen conforms to Ihering's description and has been separated as the holotype of $C$. biocellata, with the catalogue number MZUSP 1167.

We have not found any clear evidence of a specific distinctness of coastal plain material representing the nominal taxon C. biocellata and C. lacustris from the rio Paraíba do Sul and therefore synonymize $C$. biocellata with $C$. lacustris.

Whereas in preserved specimens males and females differ in the extent of the spotting of the sides, it appears as if the reddish spots of females are lost, whereas in males they are retained in preservative probably because they are underlain by more persistent melanophores. These diagnostic spots are likely a part of the breeding color pattern, unlike the head spots found in $C$. punctata, which are persistent in preservative and relatively smaller. Inasmuch as the other coastal species lack corresponding spots, the red spots on the gill cover, and perhaps those on the anterior body sides, are probably autapomorphic for C. lacustris.

\section{Crenicichla iguapina, new species}

Fig. 5

Holotype. MZUSP 49062. Young male, $126.2 \mathrm{~mm}$. Brazil, State of São Paulo, rio Ribeira de Iguape drainage, Iporanga, rio Betari, Oct 1961, H. Britski and N. A. Menezes.

Paratypes. 12 specimens, $63.5-176.3 \mathrm{~mm}$, all from State of São Paulo, rio Ribeira drainage. MCP 18241 (2, 110.2-137.2 mm), rio Ribeira, mun. Ribeira, 10 Nov 1991, C.R.Bizerril; MNRJ 6318 (2, $127.6-159.8 \mathrm{~mm})$, rio Tijuco, 200 meters from confluence with rio Ribeira, mun. Ribeira, 28 Jan 1953, E. Travassos \& H. Travassos; MZUSP 2530 (2, 141.6-164.4 mm), ribeirão Poço Grande, tributary of the rio Juquiá, mun. Juquiá, 1898; MZUSP 35308 (1, $88.8 \mathrm{~mm}$ ), ribeirão Grande, bairro Jaraçatiá, mun. Miracatu, 29 Jul 1985, O. Oyakawa. MZUSP $36540(1,89.4 \mathrm{~mm})$, stream tributary of the ribeirão Fundo, between km 15 and 16 of the road Juquiá-Sete Barras, mun. Juquiá, 12 Oct 1985, O. T. Oyakawa; MZUSP 37908 (1, 158.5 $\mathrm{mm}$ ), rio Ribeira de Iguape, mun. Registro, 12 Sept 1978, V. Lobão; MZUSP 40213 (1, $176.3 \mathrm{~mm})$, rio Pariquera-Mirim, sitio Margom, mun. Registro, 16 Aug 1985; MZUSP 41204 (1, 63.5 mm), ribeirão Poço Grande, fazenda Poço Grande, mun. Juquiá, 5 Sep 1969, H. Britski and J.C. Garavello; MZUSP 41208 (1, $105.1 \mathrm{~mm})$, rio Ribeira de Iguape, mun. Registro, 17 Feb 1956, Miguel Cuocolo.

Diagnosis. An elongate, medium sized species of the $C$. lacustris group distinguished from other species of Crenicichla along the southeastern Brazilian coast by possession of a continuous dark band along middle of side from which five paler dark bars extend to dorsal fin base, and another one or two bars to dorsal margin of caudal peduncle. Light areas present between those bars. Distinguished from C. lacustris and C. tingui, with similar color pattern, by absence of dark spots on side of head (vs. present in C. lacustris) and presence of a conspicuous suborbital marking (reduced to a small spot little below orbit and at most two more small spots below that spot in $C$. tingui). From $C$. haroldoi, $C$. jaguarensis, and C. jupiaensis, C. iguapina can be distinguished by E1 row scales counts, 60-68 (vs. 47-56); and from C. iguassuensis by having a continuous dark band along middle of side (vs. absent). Crenicichla iguapina differs from C. niederleinii by absence of narrow vertical bars crossing dark lateral band ( $v s$. present).

Description. Based primarily on specimens over $100.0 \mathrm{~mm}$. Largest male $159.8 \mathrm{~mm}$, largest female $158.5 \mathrm{~mm}$. Measurements given in Table 2, counts in Tables 4-8. See Fig. 5 for general aspect.

Comparatively deep bodied, depth 18.8-22.1\% SL. Head about as deep as wide or slightly wider than deep. Caudal peduncle longer than deep. Snout long, rounded when viewed from above, pointed in lateral view. Lower jaw prognathous. Ascending premaxillary process reaching to vertical from middle of orbit. Maxilla reaching to vertical from anterior margin of orbit or not quite so far. Upper lip thick and wide, folds not continuous but cutting into symphyseal wide thickening. Postlabial skin fold margin truncate or rounded. Lower lip fold interrupted at $4 / 5$ distance to jaw tip. Orbit supralateral, chiefly in anterior half of head, eyes not visible from below. Nostrils dorsolateral, about halfway between orbit and margin of postlabial skin fold or closer to orbit, with low elevated margin, anterior marginal skin flap absent. Preopercle regularly serrated.

Flank scales strongly ctenoid. All scales on head, anteriorly on dorsum, close along dorsal fin base, on chest, and on belly below line from lower edge of pectoral axilla to anal fin origin and along anal fin base cycloid. Predorsal scales small, superficially embedded in skin, extending forward to transverse frontal lateralis canal. Prepelvic scales very small, superficially embedded in skin. Cheek fully scaled or narrowly naked ventrally and anteroventrally; 8-9 scales rows below eye, embedded in skin. Interopercle naked. Circumpeduncular scale rows 11-13 dorsally, 12-15 ventrally (total 26-30, including lateral lines). 
Table 2. Morphometry of Crenicichla iguapina and C. tingui. $\mathrm{n}=$ number of specimens; $\mathrm{SD}=\mathrm{Standard}$ deviation.

\begin{tabular}{|c|c|c|c|c|c|c|c|c|c|c|}
\hline \multirow[b]{3}{*}{ Measurement } & \multicolumn{5}{|c|}{ C. iguapina } & \multicolumn{5}{|c|}{ C. tingui } \\
\hline & \multicolumn{4}{|c|}{ Range } & \multicolumn{6}{|c|}{ Range } \\
\hline & $\mathrm{n}$ & Min & $\operatorname{Max}$ & Mean & SD & $\mathrm{n}$ & Min & Max & Mean & SD \\
\hline \multirow[t]{2}{*}{ Standard length $(\mathrm{mm})$} & 13 & 63.5 & 176.3 & 126.8 & & 9 & 62.0 & 121.0 & 94.7 & \\
\hline & \multicolumn{10}{|c|}{ Percents of standard length } \\
\hline Body depth & 13 & 18.8 & 22.1 & 20.5 & 0.826 & 9 & 17.6 & 20.8 & 19.4 & 1.128 \\
\hline Caudal peduncle length & 13 & 14.6 & 18.0 & 15.8 & 1.079 & 9 & 13.3 & 16.4 & 14.7 & 1.075 \\
\hline Caudal peduncle depth & 13 & 9.3 & 10.8 & 10.0 & 0.364 & 9 & 9.4 & 10.7 & 9.9 & 0.441 \\
\hline Last D spine length & 12 & 8.8 & 12.5 & 10.7 & 1.189 & 9 & 8.8 & 11.7 & 10.6 & 0.832 \\
\hline Pectoral fin length & 13 & 13.4 & 19.7 & 17.4 & 1.751 & 9 & 16.3 & 19.8 & 17.8 & 1.244 \\
\hline Head length & 13 & 29.5 & 33.2 & 31.6 & 1.118 & 9 & 29.3 & 31.9 & 30.4 & 0.985 \\
\hline Head depth & 13 & 13.3 & 15.7 & 14.1 & 0.662 & 9 & 12.4 & 14.5 & 13.4 & 0.600 \\
\hline Snout length & 13 & 9.3 & 11.9 & 10.8 & 0.752 & 9 & 8.5 & 10.8 & 9.7 & 0.864 \\
\hline Orbital diameter & 13 & 5.1 & 8.7 & 6.4 & 1.034 & 9 & 5.6 & 7.6 & 6.7 & 0.676 \\
\hline Interorbital width & 13 & 5.5 & 8.5 & 6.8 & 0.898 & 9 & 5.0 & 7.4 & 5.9 & 0.863 \\
\hline Upper jaw length & 13 & 10.2 & 13.4 & 12.1 & 1.043 & 9 & 10.0 & 12.8 & 11.2 & 0.862 \\
\hline Lower jaw length & 13 & 13.5 & 17.7 & 15.4 & 1.350 & 9 & 13.8 & 16.2 & 15.4 & 0.767 \\
\hline
\end{tabular}

Scales between upper lateral line and dorsal fin 8-11 anteriorly, 4-5 posteriorly; 3 scale rows between lateral lines. Anterior upper lateral line scales slightly larger and more elongate than adjacent scales, remaining lateral line scales nearly same size as adjacent scales; 3 , occasionally 4 scales impinging on each scale of anterior portion, two on each scale of posterior portion of upper lateral line; 2 scales impinging on each scale of lower lateral line. Scales absent on dorsal, anal, pectoral, and pelvic fins. Caudal fin squamation slightly concave, marginally extending to middle of fin.

First dorsal spine about 1/3-1/4 length of last; spines increasing in length to last but subequal from about $10^{\text {th }}$. Soft part of dorsal fin rounded or pointed; both sexes sometimes with produced middle rays reaching to about base of caudal fin base. Soft anal fin with rounded or acuminate tip, not reaching to base of caudal fin. Caudal fin rounded. Pectoral fin rounded, reaching about halfway to anal fin origin. Pelvic fin inserted well posterior to vertical from pectoral axilla, with subacuminate tip; second ray longest, reaching halfway to anal fin origin; anterior rays and margin thickened.

All teeth pointed, moderately to strongly recurved. Outer row teeth distinctly larger than inner teeth and larger anteriorly than posteriorly. Upper jaw anteriorly with 4-5 inner rows; outer row teeth moveable, inner teeth inclinable or fully depressible. Lower jaw anteriorly with 3 inner rows; all teeth inclinable or depressible.

Microbranchiospines present externally on second to fourth gill arches.

Coloration in alcohol. Sexes differ in relative expression of body and fin markings: principally males with vividly spotted sides and fins, females mostly immaculate save for caudal spot. Dark brown preorbital stripe running from orbit across upper lip and around tip of lower jaw. Dark brown postorbital stripe running straight from orbit to dorsal end of gill cleft, sometimes reduced to blackish spot immediately posterior to orbit. Nuchal markings faint in large specimens, and include black spot slightly above posttemporal and triangular spot at middle of distal extrascapular. Suborbital stripe dark brown to black spot on second infraorbital, continuous with brown confluent dots on scales below, extending to $3 / 4$ or $4 / 5$ distance to preopercle; narrow in males, wide and even slightly widened distally in females; sometimes fragmented into dots on scale centres distally. Lateral line scales light with dark dot distally.

Males with numerous small dark spots scattered over middle sides and onto back. No spots on head. Holotype with spots still largely restricted to band between levels of lateral lines. Females with few spots only, or spots completely wanting from sides. Dark band along middle of side persist in females and 6 vertical dark bars descending from dorsal fin base to band enclose lightened areas over course of lateral line.

In males dorsal fin grayish with up to 6 (spinous) or 8 (soft portion) horizontal rows of dark spots. Dorsal fin in large females smoky with darker wide margin, sometimes with distinct light submarginal stripe. Dark, light-ringed spot located on middle portion of dorsal fin between $13^{\text {th }}$ and $17^{\text {th }}$ or $12^{\text {th }}$ and $17^{\text {th }}$ spines; one female (MZUSP 37908) features two ocellar spots, one between $11^{\text {th }}$ and $14^{\text {th }}$ spines, another between $14^{\text {th }}$ and $16^{\text {th }}$ spines. Soft portion of dorsal fin sometimes with few dark dots.

Anal fin grayish; in males up to four horizontal rows of dark spots on soft portion; in females anal fin immaculate or with few dark spots. Pelvic fins whitish.

In males caudal fin vividly patterned with up to 8 vertical rows of dark spots except for distal margin. Females with immaculate caudal fin or only few dark dots present. Caudal spot small, black, rounded and ocellated in both sexes; black portion extending between rays D1-D4 or V1-D3.

Smallest specimen available, $63.5 \mathrm{~mm}$ (MZUSP 41204), notably lacking suborbital spot or stripe, and flank spotting restricted to lateral band and dorsum. Dark spots on dorsal, anal and caudal fins arranged in lines. One row of spots along base of dorsal fin and another along middle of fin. On caudal fin dark spots arranged in three parallel vertical rows; distally along entire fin margin dark submarginal band followed by hyaline margin.

Young female, $89.4 \mathrm{~mm}$ (MZUSP 36540), with dark brown lateral band 3-4 scales deep, mainly between lateral line levels; scattered dark brown spots on side mainly located at lateral band and above. Dorsal fin with two rows of dark spots. Cau- 


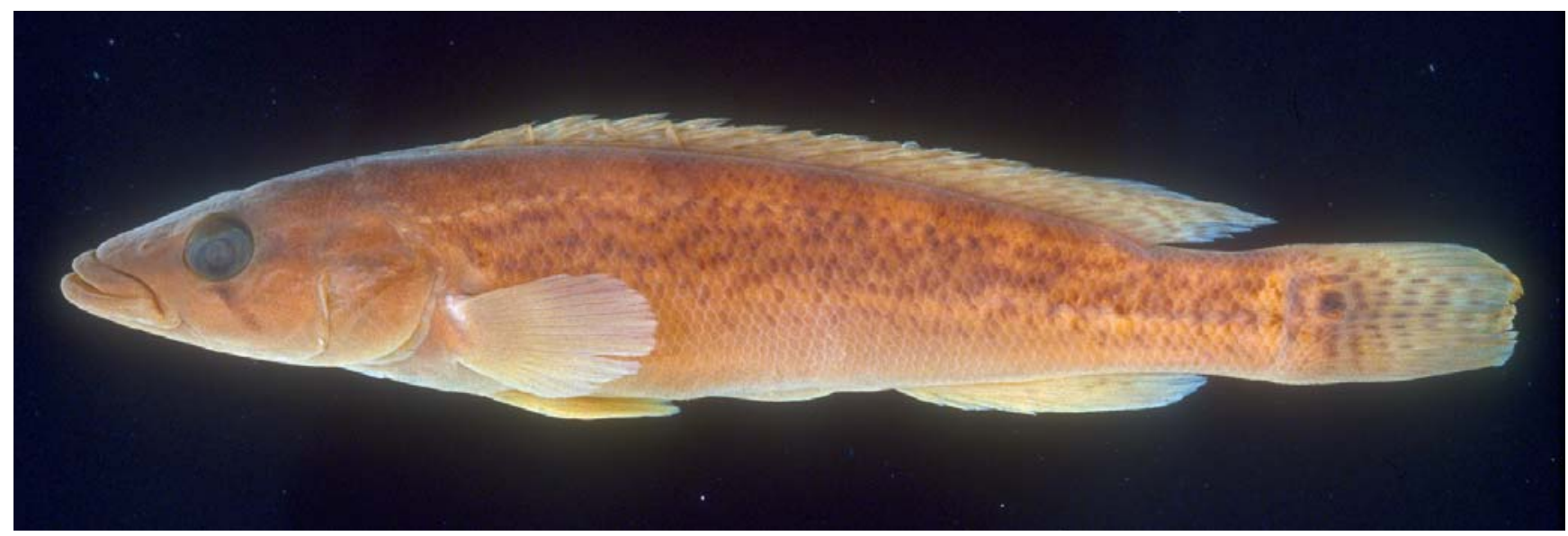

Fig. 5. Crenicichla iguapina, male, MZUSP 49062, holotype, $126.2 \mathrm{~mm}$ SL, Iporanga, rio Betari, rio Ribeira drainage, State of São Paulo, Brazil.

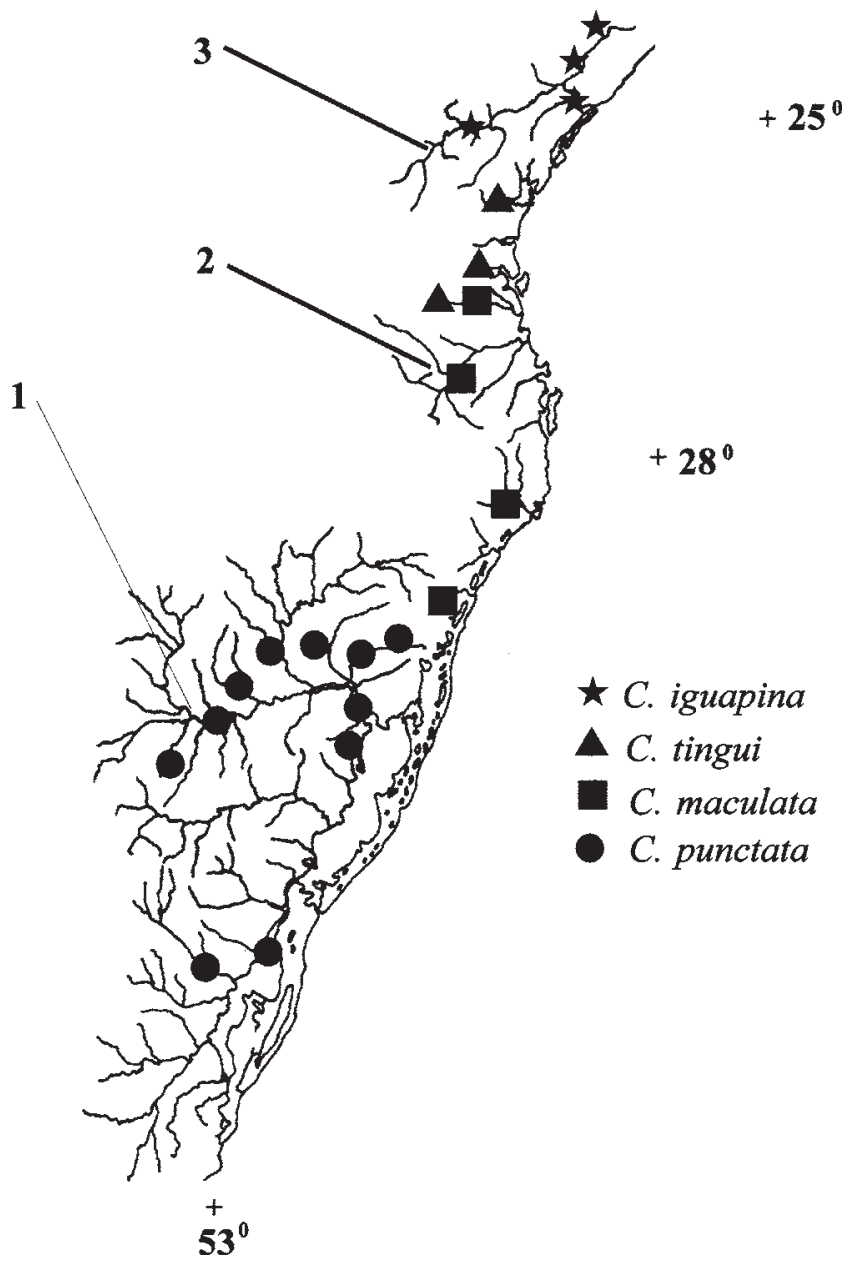

Fig. 6. Collecting localities of Crenicichla iguapina, C. tingui, C. maculata, and C. punctata in the coastal rivers of southeastern Brazil. Most important rivers are: 1. Rio Jacui (part of the laguna dos Patos System); 2. Rio Itajaí-Açu; and 3. Rio Ribeira de Iguape. A symbol may cover more than one collecting site. dal fin with small, light ringed spot between rays D1 and D4, posteriorly 3 irregular vertical rows of brown spots; caudal fin posterior margin hyaline with wide gray submarginal band.

Stomach contents. Stomachs of two specimens examined, MZUSP 37908 (158.5 mm), and MZUSP 40213 (176.3 mm), empty. Radiographed specimen MNRJ 6318 (159.8 mm) shows fish remains.

Geographical distribution. Known only from the rio Ribeira de Iguape drainage in the State of São Paulo (Fig. 6).

Etymology. Named for the river drainage in which the species appears to be endemic, the rio Ribeira de Iguape. The name is an adjective with alternative endings -inum and -inus.

Notes. The occurrence of $C$. iguapina in the rio Ribeira de Iguape reinforces the concept that this drainage is an important area of endemism. Despite the scarcity of taxonomic revisions of its fish fauna, many species have been reported exclusively from that drainage viz. Neoplecostomus ribeirensis (Langeani, 1990), Otothyris juquiae (Garavello et. al., 1998), Isbrueckerichthys alipionis and I. duseni (Pereira \& Reis, 2002), Kronichthys subteres (Weber, 2003), Pimelodella kronei and P. transitoria (Bockmann \& Guazzelli, 2003), and Hypostomus agna and H. interruptus (Oyakawa et. al., 2005).

\section{Crenicichla tingui, new species Fig. 7}

Holotype. MCP 12606. Female, 98.0 mm. Brazil, State of Paraná, municipal border Paranaguá-Morretes, rio Jacarei below the bridge

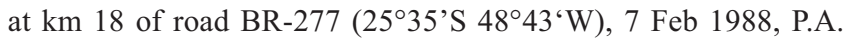
Buckup, E. Pereira \& P. Azevedo.

Paratypes. 10 specimens, $62.0-121.0 \mathrm{~mm}$, all from Brazil. Santa Catarina: MCP 6909 (2, 98.9-121.0 mm), arroio Lindo at road BR-

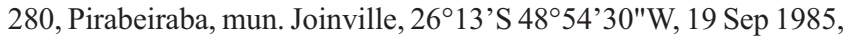
C.A.S. Lucena et al.; MCP 19892 (1, 195.0 mm), rio Ano Bom, Itapocu drainage, mun. Corupá, 1 Aug 1997, Marcelo Aranha et al.; NMW 33286 (1, 92.0 mm), mun. Joinville, 1913, V. Berndt. Paraná: 
MCP 16443 (1, $115.7 \mathrm{~mm})$, rio dos Nunes, rio Cachoeira drainage, mun. Antonina, $25^{\circ} 25^{\prime} 25^{\prime \prime S} 48^{\circ} 43^{\prime} 35^{\prime \prime} \mathrm{W}, 8$ Jan 1993, J.M.R. Aranha et al.; FMNH 54137 (5, 62.0-112.0 mm), Morretes, ca. 25²8'S $48^{\circ} 51^{\prime}$ 'W, 4 Jan 1909, J. D. Haseman (previously IUM 2702).

Diagnosis. An elongate, medium sized species of the $C$. lacustris group distinguished from all other coastal southeastern Brazilian species in color pattern. Lateral band continuous from orbit to caudal fin base, $v s$. subdivided into a row of blotches in C. punctata and C. maculata; suborbital stripe short and narrow, occasionally restricted to a small spot at orbital margin, vs. wide in C. iguapina; spots absent from side of head, vs. present in C. lacustris. The most similar species may be $C$. lacustris. In $C$. lacustris the lateral band tends to fade in males, giving way to spot pattern, and in females lateral band emphasized over spots. In C. tingui band and spotting about equally expressed, although as in other species of the C. lacustris group, body and fin spots fewer and slightly lighter in females than in males of corresponding size. Crenicichla tingui differs from all species of the $C$. lacustris group, except $C$. iguassuensis, by absence of narrow vertical stripes. Crenicichla tingui can be distinguished from $C$. iguassuensis by lateral band continuous (vs. subdivided) and by suborbital stripe short and narrow (vs. elongate, extending to or nearly to preopercle).

Description. Based primarily on specimens over $100.0 \mathrm{~mm}$. Largest male $121.0 \mathrm{~mm}$, largest female $98.9 \mathrm{~mm}$. Measurements given in Table 2, counts in Tables 4-8. See Fig. 7 for general aspect.

Comparatively elongate, depth 17.6-20.8\%. Head about as deep as wide. Caudal peduncle longer than deep. Snout long, rounded when viewed from above, pointed in lateral view. Lower jaw slightly prognathous. Ascending premaxillary process reaching to vertical from middle of orbit. Maxilla reaching to vertical from anterior margin. Upper lip thick and wide, folds not continuous but cutting into symphysial wide thickening. Postlabial skin fold margin truncate or sligthly rounded. Lower lip fold interrupted at 4/5 distance to symphysis. Orbit supralateral, not visible from below, chiefly in anterior half of head. Nostrils dorsolateral, about halfway between orbit and margin of postlabial skin fold and with low tubular margin but no anterior marginal skin flap. Preopercle regularly serrated.

Flank scales strongly ctenoid. All scales on head, anteriorly on back, along dorsal fin base, on chest, and belly below line from lower edge of pectoral axilla to anal fin origin and along anal fin base cycloid. Predorsal scales small, superficially embedded in skin, extending forward almost to transverse frontal lateralis canal. Prepelvic scales very small, superficially embedded in skin. Cheek fully scaled or narrowly naked ventrally and anteroventrally; 6-9 scales rows below eye, embedded in skin. Interopercle naked. Circumpeduncular scale rows 12-13 dorsally, 12-15 ventrally (25-28 including lateral lines).

Scales between upper lateral line and dorsal fin 11-12 ante- riorly, 4-5 posteriorly; 3 scale rows between lateral lines. Anterior upper lateral line scales slightly larger and more elongate than adjacent scales, remaining lateral line scales nearly same size as adjacent scales; three scales impinging on each scale of anterior part, two on each scale of posterior part of upper lateral line; 2 scales impinging on each scale of lower lateral line. Dorsal, anal, pectoral, and pelvic fins without scales. Caudal fin squamation concave, marginally extending to middle of fin.

First dorsal spine about 1/3-1/4 length of last; spines increasing in length to last but subequal from about $10^{\text {th }}$. Soft part of dorsal fin pointed; both sexes sometimes with produced middle rays, reaching to about base of caudal fin. Soft anal fin with acuminate tip; in both sexes not reaching to base of caudal fin. Caudal fin rounded. Pectoral fin rounded, reaching about halfway to anal fin origin. Pelvic fin inserted well posterior to vertical from pectoral axilla, with acuminate tip, second ray longest, reaching about halfway to anal fin origin; anterior rays and margin thickened.

All teeth pointed, slightly to strongly recurved. Outer row teeth slightly larger than inner teeth and larger anteriorly than posteriorly. Upper jaw anteriorly with 4-5 inner rows; outer row teeth movable, inner teeth inclinable or fully depressible. Lower jaw anteriorly with 3 inner rows; all teeth inclinable or depressible.

Microbranchiospines well developed, present externally on second to fourth gill arches.

Coloration in alcohol. Males and females similar in body color pattern, but males with more numerous and more distinct spots in unpaired fins. Dark brown preorbital stripe running from orbit across upper lip and around tip of lower jaw to dorsal end of gill cleft. Nuchal marks faintly expressed and including blackish spot slightly above posttemporal bone and dark band along margins of scales above sphenotic bone. Suborbital marking consisting of black spot on second infraorbital bone and brownish dots on one or two scales below, at best extending as pointed stripe down to middle of cheek as in holotype.

Wide blackish lateral band about four scales deep throughout or three scales deep anteriorly, running from pectoral girdle to caudal fin base, slightly separated from upper lateral line except at its end and extending ventrally onto scales of lower lateral line.

Five to seven dark vertical bars between dorsal fin base and upper lateral line, and two dark blotches sometimes discerned on dorsal part of caudal peduncle. Lateral line scales light with dark brown dot distally.

Minute black spots cover lateral band and posterior 3/4 of back in holotype; in others also in irregular horizontal row slightly ventral to lateral band. No dark spots on head other than those forming suborbital marking.

In males dorsal fin hyaline to whitish with dark spots along both spinous and soft portions, arranged in 2-3 horizontal rows anteriorly, 3-4 rows posteriorly; in females spotting distinct only posteriorly in fin. Anal fin hyaline or whitish with grayish lower margin and scattered dark dots more or less distinct in 2-3 horizontal rows on soft portion. Pelvic fin whit- 


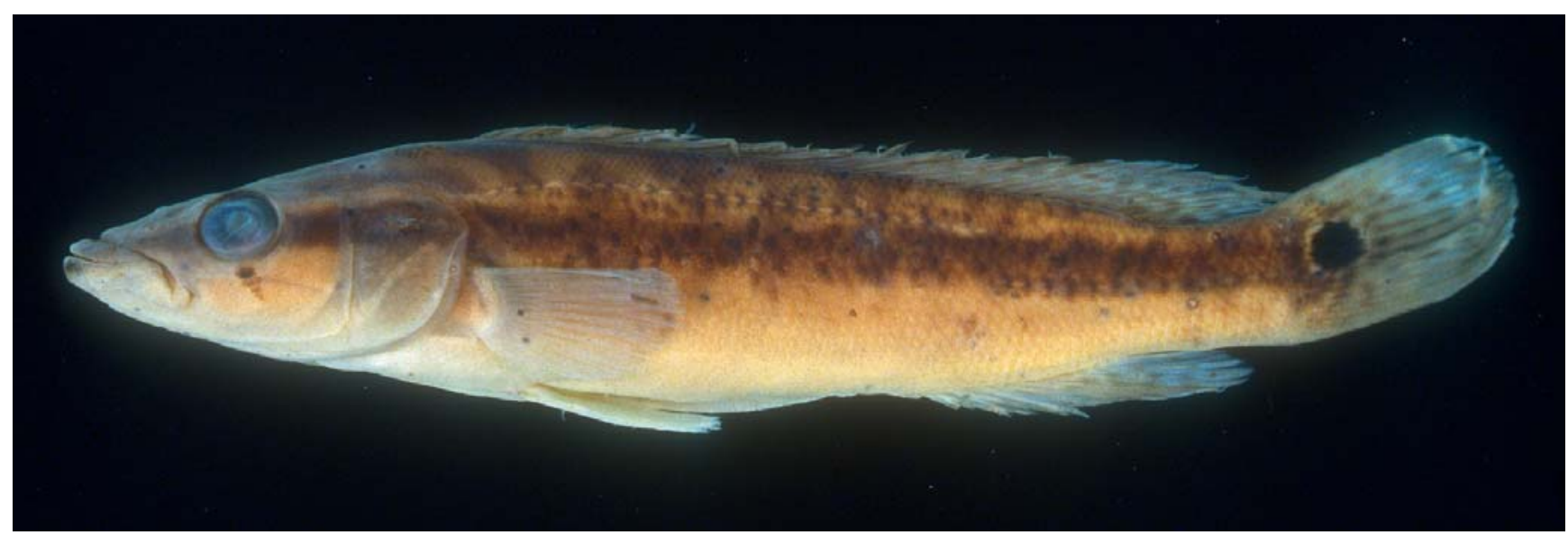

Fig. 7. Crenicichla tingui, female, MCP 12606, holotype, $98.0 \mathrm{~mm}$ SL, municipal border Paranaguá-Morretes, rio Jacarei, State of Paraná, Brazil.

ish. Caudal fin hyaline or whitish with seemingly irregularly distributed large gray dots, corners hyaline with dark submarginal band (not showing clearly).

Caudal spot conspicuous in specimens from Paranaguá catchment, large, extending between rays V1 and D5, deep black, rounded and margined with white ring, but less contrasted and appearing smaller in arroio Lindo sample. Pelvic and pectoral fins white and without marks.

Stomach contents. Single specimen examined, MCP 19892 $(195.0 \mathrm{~mm})$, contained chiefly remains of fishes.

Geographical distribution. Crenicichla tingui was collected in the rio Itapocu drainage and in small coastal rivers draining to the baía de Babitonga (rio Cubatão drainage) and the baía de Paranaguá (rio Jacarei and rio Cachoeira drainages) (Fig. 6).

Etymology. Tingui is a Tupi word used in southern Brazil to designate an origin or inhabitant of the State of Paraná. It is here used as a noun in apposition.

Notes. FMNH 54137 specimens were listed by Haseman (1911:351) as Crenicichla lacustris, with only the remark 'One has A. III,10'.

\section{Crenicichla maculata, new species} Fig. 8

Holotype. MCP 14661. Young female, $96.3 \mathrm{~mm}$. Brazil, State of Rio Grande do Sul, Maquiné, rio Pinheiro, 14 Jan 1991, N. Menezes, R. Reis \& E.H.L. Pereira.

Paratypes. 59 specimens, 61.8-211.5 mm. Santa Catarina: rio Tubarão drainage: $\mathrm{MCP} 11080(5,31.0-116.1 \mathrm{~mm})$, rio Capivari road Gravatal-Armazém, 10 Dec 1986, C. Lucena et al. Rio ItajaíAçu drainage: MCP 16479 (5, 83.6-116.6 mm), ribeirão São Luis, mun. Apiúna, 15 Oct 1993, C. Lucena et al.; MCP 16529 (3, 67.2$117.4 \mathrm{~mm}$ ), same data as MCP 16479. Rio Itapocu drainage: NMW 32818 (1, 247.0 mm), Joinville, Dez 1908, Erhardt; NMW 33131132 (2, 137.8-155.5 mm), Paul Fluss, 1910 [probably some place near Joinville city); NMW 33144 (1, $110.4 \mathrm{~mm}$ ), rio Isabel [probably rio Isabela, a tributary of rio Novo, near Corupá]; NMW 33145-146 (2, 102.7-108.6 mm), rio Isabel (same observations above as NMW 33144), 1910, Erhardt; NMW 33191 (3, 94.7-133.0 mm), rio Novo, Apr 1910, Erhardt; NMW 33198 (3, 101.2-131.9 mm), rio Novo, 1910, Erhardt; NMW 33206-208 (3, 119.7-133.1 mm), rio Novo, Apr 1910, Erhardt; NMW 33242 (1, 235.0 mm), Joinville, Jan 1909; NMW 33287 (1, 74.0 mm), Joinville, 1913, Berndt; Rio Grande do Sul: rio Maquiné-lagoa dos Quadros drainage: MCP 10767 (1, 129.1 $\mathrm{mm}$ ), rio Maquiné, mun. Osório, 25 May 1986, C. Lucena et al.; MCP 13609 (2, 78.3-81.9 mm), rio Maquiné near Maquiné, mun. Osório. 1 Oct 1989, S.O. Kullander et al.; MCP 13924 (1, 123.8 $\mathrm{mm}$ ), lagoa dos Quadros at bridge of Parque Náutico, mun. Capão da Canoa, 31 Mar 1990, A. Ramires \& B. Dyer; MCP 14662 (2, 70.3 $100.1 \mathrm{~mm}$ ), rio Mitmann, Vila Nova at $10 \mathrm{~km}$ of the road BR101, mun. Terra de Areia, 15 Jan 1991, N.A.Menezes et al.; MCP 15275 (13, 104.8-191.7 mm), lagoa do Palmital, 7 Nov 1991, L. Malabarba et al.; MCP 15276 (5, 164.6-184.7 mm), lagoa dos Quadros, near the Estação de Piscicultura, mun. Terra de Areia, 13 Nov 1991. L. R. Malabarba et al. ; MCP 15278 (3, 84.0-189.0 mm), arroio do Ouro, between Maquine and Barra do Ouro, 19 Nov 1990, L.R. Malabarba \& A. Kindel; MCP 16313 (4, 113.5-179.8 mm), lagoa Emboaba, mun. Tramandaí, 1992, S. Hartz \& W. Bruschi Jr.; NRM 26077 (2, 79.5-79.6 mm S:L), rio Maquiné near Maquiné, 1 Oct 1989, S.O. Kullander et al. Rio Três Forquilhas-lagoa Itapeva drainage: MCP 6061 (4, 79.8-163.1 mm), rio Três Forquilhas, Porto Alágio, mun. Torres, 25 May 1986, C. Lucena et al.; MCP 11257 (6, 61.8-211.5 $\mathrm{mm})$, rio Três Forquihas, mun. Torres, 28 Apr 1987, A. Bergmann \& P. Azevedo; MCP 14273 (2, 70.0-128.5 mm), rio Três Forquilhas on road Três Forquilhas-Itati, mun.Torres, ca. $50^{\circ} 05^{\prime} \mathrm{W} 29^{\circ} 30^{\prime} \mathrm{S}, 12$ Dec 1989, Margarete Lucena et al.; MCP 14308 (1, $114.8 \mathrm{~mm})$, rio Três Forquilhas, mun. Torres, 12 Dec 1989, M. Lucena et al.

Diagnosis. An elongate, large sized species of the C. lacustris group. Crenicichla maculata differs from all other coastal southeastern Brazilian species by the presence of a row of 5-8 dark blotches along middle of side and narrow vertical bars absent $v s$. presence of a continuous lateral band and vertical bars in C. mucuryna. Crenicichla maculata is most similar to C. punctata in color pattern, males always feature a pattern of irregularly distributed dark spots over the sides, whereas this pattern is lost in breeding females. Crenicichla maculata differs from $C$. punctata in absence of minute dark spots on the 
Table 3. Morphometry of Crenicichla maculata and C. punctata. $\mathrm{SD}=\mathrm{Standard}$ deviation.

\begin{tabular}{|c|c|c|c|c|c|c|c|c|c|c|}
\hline \multirow[b]{3}{*}{ Measurement } & \multicolumn{5}{|c|}{ C. maculata } & \multicolumn{5}{|c|}{ C. punctata } \\
\hline & \multicolumn{4}{|c|}{ Range } & & \multicolumn{4}{|c|}{ Range } & \multirow[b]{2}{*}{ SD } \\
\hline & $\mathrm{n}$ & Min & Max & Mean & SD & $\mathrm{n}$ & Min & $\operatorname{Max}$ & Mean & \\
\hline \multirow[t]{2}{*}{ Standard length $(\mathrm{mm})$} & 57 & 61.8 & 211.5 & 120.9 & & 23 & 78.5 & 224.4 & 132.4 & \\
\hline & \multicolumn{10}{|c|}{ Percents of standard length } \\
\hline Body depth & 55 & 17.9 & 24.1 & 20.6 & 1.616 & 23 & 19.0 & 26.3 & 21.8 & 1.676 \\
\hline Caudal peduncle length & 57 & 12.9 & 17.3 & 14.9 & 0.957 & 23 & 14.6 & 17.6 & 15.9 & 0.884 \\
\hline Caudal peduncle depth & 57 & 8.8 & 11.8 & 10.5 & 0.625 & 23 & 10.1 & 11.9 & 11.0 & 0.516 \\
\hline Last D spine length & 57 & 7.7 & 12.5 & 9.8 & 1.141 & 18 & 7.8 & 11.6 & 10.1 & 0.919 \\
\hline Pectoral fin length & 57 & 15.7 & 21.7 & 18.3 & 1.112 & 23 & 15.4 & 21.3 & 17.7 & 1.267 \\
\hline Head length & 57 & 29.2 & 35.0 & 31.7 & 1.069 & 23 & 28.5 & 32.3 & 30.8 & 1.069 \\
\hline Head depth & 56 & 12.5 & 17.0 & 14.4 & 0.924 & 23 & 13.2 & 17.0 & 15.1 & 0.926 \\
\hline Snout length & 55 & 8.8 & 12.9 & 10.7 & 0.859 & 23 & 9.2 & 11.7 & 10.3 & 0.699 \\
\hline Orbital diameter & 57 & 5.0 & 8.6 & 6.6 & 0.891 & 23 & 5.1 & 7.0 & 6.1 & 0.634 \\
\hline Interorbital width & 57 & 4.6 & 8.1 & 6.0 & 0.954 & 23 & 4.6 & 8.6 & 6.4 & 1.025 \\
\hline Upper jaw length & 55 & 9.9 & 14.0 & 11.7 & 1.048 & 22 & 9.7 & 14.1 & 11.5 & 0.872 \\
\hline Lower jaw length & 55 & 13.2 & 17.2 & 15.2 & 1.044 & 22 & 13.9 & 17.4 & 15.1 & 0.768 \\
\hline
\end{tabular}

head. From C. haroldoi, C. jaguarensis, and C. jupiaensis, $C$. maculata can be distinguished by E1 row scale counts, 60-75, one specimen with 58 (vs. 47-56). From C. iguassuensis, with similar color pattern, $C$. maculata differs by presence of a row of 5-8 dark blotches along side and snout pointed with lower jaw distinctly prognathous (vs. 4-5 dark blotches, snout blunt with lower jaw slightly prognathous). Crenicichla maculata differs from $C$. niederleinii by absence of narrow vertical bars.

Description. Based primarily on specimens about $100.0 \mathrm{~mm}$ and larger. Largest male $191.7 \mathrm{~mm}$, largest female $211.5 \mathrm{~mm}$. Measurements given in Table 3, counts in Tables 4-8. See Fig. 8 for general aspect.

Comparatively deep bodied, body depth 17.9-24.1\% SL. Head nearly always slightly wider than deep, sometimes about as deep as wide. Caudal peduncle longer than deep. Snout long, rounded when viewed from above, moderately pointed in lateral view. Lower jaw prognathous. Ascending premaxillary processes reaching to vertical from middle of orbit. Maxilla reaching to vertical from anterior margin of orbit or slightly beyond. Upper lip thick and wide, folds not continuous but cutting into symphyseal wide thickening. Postlabial skin fold margin rounded. Orbit supralateral, eye not visible from below, chiefly in anterior half of head. Nostrils dorsolateral, about halfway between orbit and margin of postlabial skin fold and with slightly elevated margin but no anterior marginal skin flap. Preopercle regularly serrated.

Flank scales strongly ctenoid. All scales on head, anteriorly on back to middle of upper lateral line, along dorsal fin base, on chest, and belly below line from lower edge of pectoral axilla to anal fin origin and along anal fin base cycloid. Predorsal scales small, superficially embedded in skin, extending forward to transverse frontal lateralis canal. Prepelvic scales very small, superficially embedded in skin. Cheek fully scaled or narrowly naked ventrally and anteroventrally; 5-9 scales rows below eye, embedded in skin. Interopercle naked. Circumpeduncular scale rows 11-14 dorsally, 11-15 ventrally (total 26-31 including lateral lines).

Scales between upper lateral line and dorsal fin 10-14 anteriorly, 4-7 posteriorly; 3 scale rows between lateral lines. Anterior upper lateral line scales slightly larger and more elongate than adjacent scales, remaining lateral line scales almost same size as adjacent scales; 3 scales impinging on each scale of anterior part, 2 on each scale of posterior part of upper lateral line; 2 scales impinging on each scale of lower lateral line. Scales absent from dorsal, anal, pectoral, and pelvic fins. Caudal fin squamation concave, marginally extending to middle of fin.

First dorsal spine about 1/3-1/4 length of last; spines in-

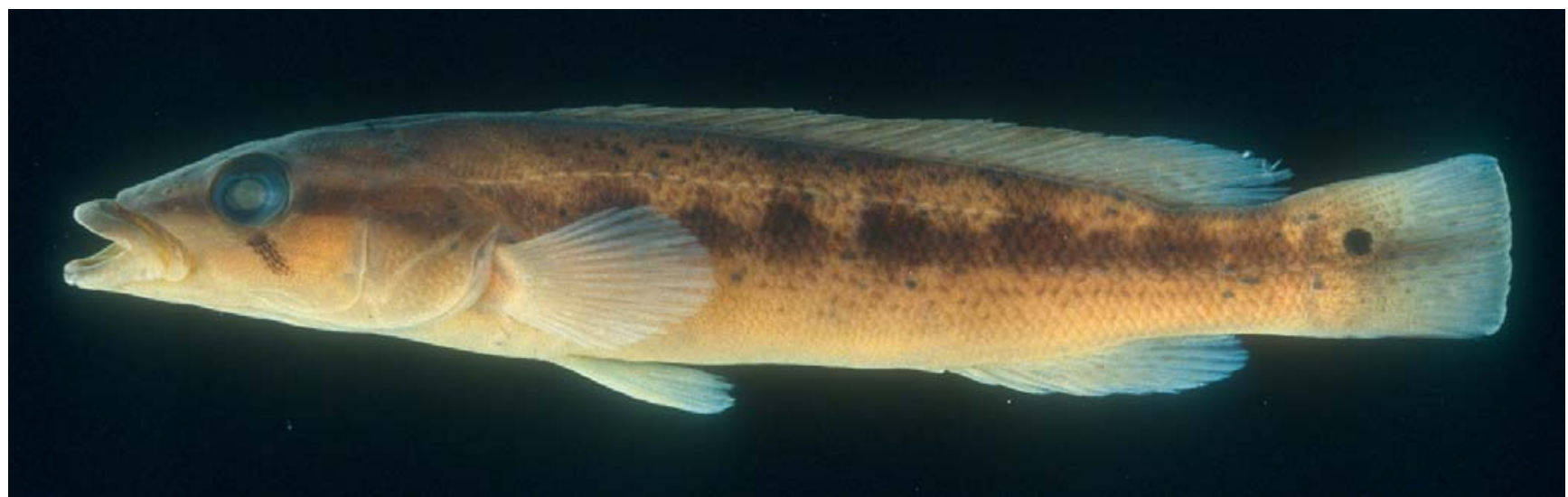

Fig. 8. Crenicichla maculata, female, MCP 14661, holotype, $96.3 \mathrm{~mm}$ SL, Maquiné, rio Pinheiro, State of Rio Grande do Sul, Brazil. 
creasing in length to last but subequal from about $10^{\text {th }}$. Soft part of dorsal fin rounded or subacuminate, reaching to about base of caudal fin. Soft anal fin with rounded tip, not reaching to caudal fin base. Caudal fin rounded. Pectoral fin rounded, reaching halfway to anal fin origin. Pelvic fin inserted well posterior to vertical from pectoral axilla, with rounded tip, second ray longest, reaching halfway to anal fin origin; anterior rays and margin not particularly thickened.

All teeth pointed, slightly recurved. Outer row teeth distinctly larger than inner teeth and larger anteriorly than posteriorly. Upper jaw anteriorly with 4-5 inner rows; all teeth inclinable or depressible. Lower jaw anteriorly with 3 inner rows; all teeth inclinable or depressible.

Microbranchiospines present externally on second to fourth gill arches.

Lower pharyngeal tooth plate in $136 \mathrm{~mm}$ specimen, MCP 11257 (Fig. 9), strongly compressed dorsoventrally, slightly wider than long and with wide dentigerous area (length of bone including posterior muscular processes $93 \%$ of width, along midline $68 \%$ of width; dentigerous area length $76 \%$ of dentigerous area width; dentigerous area midline length $65 \%$ of dentigerous area width). Teeth fairly short laterally, gradually increasing in size caudally and medially, teeth in posterior row markedly longer than other teeth. On anterior half of bone and along margins unicuspid, pointed, with caudad curved tips; centrally rounded in cross section, with more or less central, worn cusp; posterior row teeth and few adjacent teeth with posterior rostrad curved cusp and subapical narrow shelf anteriorly. Posterior and posterolateral teeth more or less compressed in cross section, remainder rounded in cross section. 18 teeth in posterior row, 8-9 irregularly arranged teeth in midline row.

Coloration in alcohol. Dark brown preorbital stripe from orbit across upper lip and around tip of lower jaw. Dark brown postorbital stripe running straight from orbit to dorsal end of gill cleft, but sometimes reduced to blackish spot immediately posterior to orbit. Suborbital stripe as wide as pupil or slightly narrower, slightly caudad inclined, extending to or almost to margin of preopercle; proximally (on second infraorbital) entire, deep black, gradually more fragmented distally into blackish to brown spots on scale centers. Nuchal markings faint in larger specimens, but well marked in smaller specimens, including black spot little above posttemporal, spot occasionally elongated to form stripe along margin of predorsal squamation above sphenotic, and triangular spot at posterior middle of distal extrascapular.

Basic body pattern consisting of series of 5-8 dark brown to blackish, rounded or slightly elongated blotches along middle of side slightly below upper lateral line scale row, continued along caudal peduncle immediately above lower lateral line. Blotches as well as last blotch and caudal peduncle band connected by dark brown pigment given appearance of band with portions intensified. Blotches appear at irregular intervals, and another one or two blotches may appear interspersed between others or as a result of division of regular spot. Slightly paler dark vertical bars extending between lateral blotches and dorsal fin base; often resulting in pattern of series of light blotches along sides of back. Lateral line scales light with dark dot distally.

Young specimens, males and most females with numerous minute dark spots irregularly distributed over body, excepting only head, chest, lower side of abdomen, along base of anal fin and ventrally on caudal peduncle. Breeding females completely lack minute dark spots. One male (MCP $11080,114.4 \mathrm{~mm}$ ), apparently in breeding color, overall light, with lateral blotches having nearly disappeared and conspicuous contrasting pattern of dark dots.

Unpaired fins marked with small, irregularly distributed dark spots, in about 3 (anteriorly) to 6 (posteriorly) horizontal rows on dorsal fin, up to about 7 vertical rows on caudal fin, and up to about 6 horizontal rows on anal fin. Caudal fin also with faintly expressed dark submarginal band along posterior margin. Caudal spot small, extending between rays D1 and D4, black, rounded or vertically ovate, usually with light margin only along margin toward caudal fin base, but sometimes fully ocellated. In young specimens spot fully ocellated, whereas in specimens understood as showing breeding color pattern light ring sometimes completely lost. Pelvic fin white and without markings.

In breeding females spots absent or few and indistinct in unpaired fins; dorsal fin in females smoky with darker wide margin, occasionally with distinct light submarginal stripe. Dark blotch or ocellus on middle portion of dorsal fin absent in all females.

Stomach contents. One specimen, $182.7 \mathrm{~mm}$ (MCP 15276) contained mostly molluscs shells (bivalves) but also coleopteran larvae. Another specimen,191.7 mm (MCP 15275) contained remains of fishes and a gastropod mollusc.

Geographical distribution. Four areas of distribution are represented in our material. Most specimens come from a limited area north of laguna dos Patos, viz. the lower rio Maquiné, lower rio Três Forquilhas, lagoa dos Quadros, lagoa do Palmital and lagoa Emboaba, State of Rio Grande do Sul. To the north there is one sample from the rio Tubarão drainage, one from ribeirão São Luis in the rio Itajaí-Açu drainage, and another from the rio Itapocu drainage (Fig. 6) all in the State of Santa Catarina.

Notes. Crenicichla maculata is very similar to C. punctata and replaces $C$. punctata in drainages immediately north of the laguna dos Patos. The two species share a general color pattern consisting of a row of dark blotches along the middle of the side and numerous dark spots scattered over sides and fins. Crenicichla maculata can be distinguished by reference to the head coloration. In C. punctata both males and females have dark spots on the head similar to spots on the sides, but the spotting does not advance anterior to the first side blotch in C. maculata. Breeding females of C. punctata, however, may lack head spots and thus be indistinguishable from $C$. 


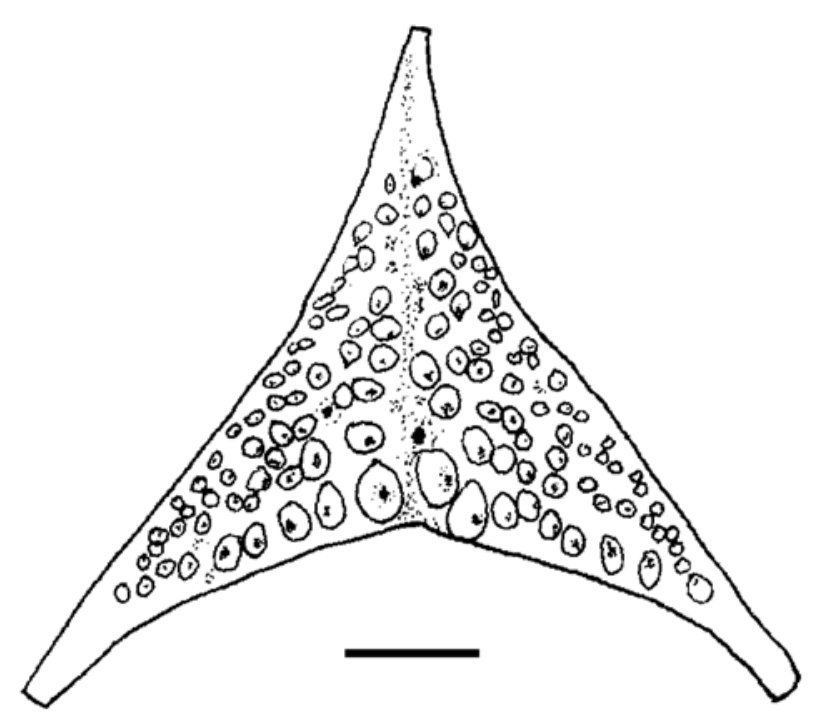

Fig. 9. Crenicichla maculata, lower pharyngeal tooth plate in occlusal aspect, MCP 11257 (133.7 mm SL).

maculata specimens. The suborbital stripe is generally wider and longer in C. maculata (4-8 scales wide, extending to the preopercular margin) than in C. punctata (3-5 scales wide, extending to middle or $4 / 5$ the distance to the preopercular margin), but several specimens remain unidentifiable using stripe width alone. There are no differences in fin or scale counts.

\section{Crenicichla punctata Hensel}

Fig. 10

Crenicichla punctata Hensel, 1870: 57 (Type-locality: aus dem Guahyba bei Porto Alegre ... Bächen des Urwaldes ... Waldbächen von der deutschen Colonie Sta. Cruz in Rio Grande do Sul).

Crenicichla polysticta Hensel, 1870: 58 (Type-locality: Rio Cadea des Urwaldes von Rio Grande do Sul).

Material examined. 67 specimens, 29.7-290.0 mm. Rio Grande do Sul: ZMB 7459 (1, $149.0 \mathrm{~mm}$ ), rio Guaíba, mun. Porto Alegre, no date, R. Hensel, lectotype of Crenicichla punctata; ZMB 32679 (1, $90.4 \mathrm{~mm})$, rio Guaíba, mun. Porto Alegre, no date, R. Hensel, paralectotype of Crenicichla punctata; ZMB 25151 (4, ca. 26.0$28.5 \mathrm{~mm}$ ), colonia Sta. Cruz, no date, R. Hensel, paralectotypes of Crenicichla punctata; ZMB 7460 (2, not measured), colonia Sta. Cruz, no date, R. Hensel, paralectotypes of Crenicichla punctata; ZMB 25127 (3, 75.1-132.9 mm), colonia Sta. Cruz, no date, R. Hensel, paralectotypes of Crenicichla punctata; MCP $9689(1,111.1$ $\mathrm{mm}$ ), Ponta Grossa, lago Guaíba, mun. Porto Alegre; MCP 9947 (1, $96.8 \mathrm{~mm}$ ), Ponta Grossa, lago Guaíba, mun. Porto Alegre; MCP 10921 (1, $113.3 \mathrm{~mm})$, rio Ibicuí, near the mouth, mun. Itaqui; MCP $11120(1,130.3 \mathrm{~mm})$, lago Guaíba at ilha do Junco, mun. Porto Alegre; MCP 13140 (2, 245.0-290.0 mm), lago Guaíba, near ilha do Junco, mun. Viamão; MCP 13510 (1, $199.6 \mathrm{~mm})$, rio dos Sinos, mun. Santo Antônio da Patrulha; MCP 15034 (2, 78.5-115.8 mm), arroio Gaguas, mun. Feliz; MCP 15067 (3, 40.8-45.8 mm), arroio afluente do rio dos Sinos, mun. Sapiranga; MCP 15997 (2, 63.8$70.8 \mathrm{~mm}$ ), lago Guaíba, praia de Itapuã, mun. Viamão; MCP 16625
(1, 66.8 mm), arroio Santa Bárbara, $12 \mathrm{~km}$ a oeste da Vila do Segredo, mun. Caçapava do Sul; MCP 16450 (5, 121.2-176.9 mm), lago Guaíba at bridge of the Figueira, mun. Guaíba; MCP 14384 (1, $189.7 \mathrm{~mm}$ ), lagoa Guaíba at Parque da Harmonia, mun. Porto Alegre; MCP 6871 (2, 83.7-92.0 mm), lago Guaíba, Ponta Grossa, mun. Porto Alegre; MCP 7914 (1, 76.4 mm), açude dos Garcia (BR 116, km 56), mun. Barra do Ribeiro; MCP 9291 (1, 93.0 mm), arroio Paraíso, Rincão da Porta, mun. Cahoeira do Sul; MCP 9799 ( 2 , 57.4-96.5 mm), arroio Sampaio, Cruzeiro do Sul; MCP 10540 (3, 212.0-223.0 mm), lago Guaíba at ponta do Jacaré, mun. Barra do Ribeiro; MCP 10601 (2, 95.0-100.0 mm), lago Guaíba, ilha do Junco, mun. Viamão, about 30²0’40"S 512'29"W; MCP 11121 (6, 100.0-156.8 mm), lago Guaíba; MCP 11224 (1, $133.0 \mathrm{~mm})$, bridge over rio Caí, road São Sebastião do Caí/Bom Princípio; MCP 1244 (7, 101.0-218.6mm), mouth of rio Telho into rio Jaguarão, mun. Jaguarão; MCP 11312 (3, one measured, $171.8 \mathrm{~mm}$ ), lagoa Mirim; MCP $11362(1,35.4 \mathrm{~mm})$, rio Caí at bridge on road CaxiasPorto Alegre; MCP 11363 (3, 29.7-34.0 mm), road to Pareci Novo, São Sebastião do Caí; MCP 13187 (2, 79.0-100.0 mm, cleared and stained), lago Guaíba, between Guaíba and Barra do Ribeiro; MCP $21264(1,125.0 \mathrm{~mm})$, arroio da Gringa, rio Jacuí drainage.

Diagnosis. An elongate, large sized species of the $C$. lacustris group. Similar to C. maculata and different from C. tingui, $C$. iguapina, and $C$. lacustris in having a row of about five dark blotches along middle of side, slightly separated from upper lateral line, followed by two often contiguous blotches, or forming a band, continuing blotch row on caudal peduncle. A pattern of irregularly distributed dark spots on flanks present in both sexes, but may be absent in breeding females. Different from C. maculata in presence of small dark spots on side of head, vs. absent. From remaining species in the $C$. lacustris group, C. punctata differs by absence of narrow vertical bars vs. present except in $C$. iguassuensis, and by presence of small dark spots on side of head of males vs. absence.

Description. Based primarily on specimens over $100 \mathrm{~mm}$. Largest male $290.0 \mathrm{~mm}$, largest female $225.0 \mathrm{~mm}$. Measurements given in Table 3, counts in Tables 4-8. See Fig. 10 for general aspect.

Comparatively deep bodied, depth 19.0-26.3\% SL. Head about as deep as wide or slightly deeper than wide. Caudal peduncle longer than deep. Snout moderately long, rounded when viewed from above, pointed in lateral view. Lower jaw prognathous. Ascending premaxillary process reaching to $1 / 3$ of orbit. Maxilla reaching to vertical from anterior margin of orbit or, in large specimens, not quite so far. Upper lip moderately thick, folds not continuous but cutting into symphyseal narrow thickening. Postlabial skin fold margin rounded. Orbit supralateral, not visible from below, chiefly in anterior half of head. Nostrils dorsolateral, about halfway between orbit and margin of postlabial skin fold and with low tubular margin but no anterior marginal skin flap. Preopercle regularly serrated.

Flank scales strongly ctenoid. All scales on head, anteriorly on back, along dorsal fin base, on chest, and belly below line from lower edge of pectoral axilla to anal fin origin and along anal fin base cycloid. Predorsal scales small, superficially embedded in skin, extending forward to transverse frontal lateralis canal. Prepelvic scales very small, superficially em- 
Table 4. E1 scale count frequencies in species of Crenicichla. ${ }^{1} \mathrm{MNHN}$ A9501 (126.0 mm), syntype of C. lacustris; ${ }^{2}$ includes FMNH 54155 (117.0 mm), some scales missing; holotype of $C$. dorsocellata; ${ }^{3}$ includes lectotype of $C$. mucuryna MZUSP 2526 (113.3 mm).

\begin{tabular}{lcccccccccccccccccc}
\hline & 56 & 57 & 58 & 59 & 60 & 61 & 62 & 63 & 64 & 65 & 66 & 67 & 68 & 69 & 70 & 71 & 73 & 75 \\
\hline C. mucuryna & & 3 & 1 & 2 & 2 & $4^{3}$ & 3 & 1 & & & & & & & & & & \\
C. lacustris (except rio Doce lakes) & & $1^{1}$ & & & 1 & 1 & & 6 & & 6 & $5^{2}$ & 4 & 3 & 1 & 2 & 1 & & \\
C. lacustris (rio Doce lakes) & & & & & 1 & & & 1 & 1 & 5 & 4 & 4 & 5 & 1 & 1 & 2 & & 1 \\
C. iguapina & & & & & 1 & & 2 & 3 & & 2 & 2 & 1 & 1 & & & & & \\
C. tingui & & & & & & & 1 & 1 & 1 & 1 & 1 & 2 & 3 & & & & \\
C. maculata & 1 & & 1 & & 3 & 4 & 7 & 5 & 9 & 8 & 8 & 7 & 10 & 7 & 3 & 1 & 1 & 1 \\
C. punctata & 1 & & 2 & & 2 & 3 & 2 & 1 & 2 & 2 & 1 & 2 & & 2 & 2 & & & \\
\hline
\end{tabular}

bedded in skin. Cheek fully scaled or narrowly naked ventrally and anteroventrally; 6-9 scales rows below eye, embedded in skin. Interopercle naked. Circumpeduncular scale rows 12-13 dorsally, 11-14 ventrally (total 24-27, including lateral lines).

Scales between upper lateral line and dorsal fin 7-11 anteriorly, 4-5 posteriorly; scale rows between lateral lines 3. Anterior upper lateral line scales slightly larger and more elongate than adjacent scales, remaining lateral line scales nearly same size as adjacent scales; three scales impinging on each scale of anterior part, two on each scale of posterior part of upper lateral line; 2 scales impinging on each scale of lower lateral line. Dorsal, anal, pectoral, and pelvic fins without scales. Caudal fin squamation concave, marginally extending to middle of fin.

First dorsal spine about 1/3-1/4 length of last; spines increasing in length to last but subequal from about $10^{\text {th }}$. Soft part of dorsal fin pointed, reaching to about base of caudal fin or slightly beyond. Soft anal fin with subacuminate tip, not reaching to caudal fin base. Caudal fin rounded. Pectoral fin rounded, reaching halfway to anal fin origin. Pelvic fin inserted well posterior to vertical from pectoral axilla, with acuminate tip, second ray longest, reaching halfway to anal fin origin; anterior rays and margin slightly thickened.

All teeth pointed, slightly recurved. Outer row teeth distinctly larger than inner teeth and larger anteriorly than posteriorly. Upper jaw anteriorly with 4-5 inner rows; all teeth inclinable or depressible. Lower jaw anteriorly with 3 inner rows; all teeth inclinable or depressible.

Microbranchiospines present externally on $2^{\text {nd }}$ to $4^{\text {th }}$ arches.

Coloration in alcohol. Snout and dorsal surface of head anterior to predorsal squamation gray. Lower jaw, cheeks, and un- derside of head yellowish or whitish. Dark brown preorbital strip from eye to tip of lower jaw. Dark brown postorbital stripe form eye to opercular tip, usually restricted to dark blotch between eye and preopercle. In few specimens pale blotch on posttemporal and also pale triangular spots on extrascapular series. Black suborbital stripe narrow, extending to middle or 4/ 5 distance to preopercle, proximally entire, distally or for most of length with pigmentation on scale centers deeper.

Both sexes with sides, dorsum, dorsal and anal fins covered with numerous irregularly distributed dark spots, all smaller than pupil. Spot pattern extends onto nape and sides of head, including gill cover and posterior half of cheek. Spots sometimes absent from head and most of body sides in females, probably as part of breeding color pattern.

Five wide dark vertical bars extending down from dorsal fin base, all except first and occasionally fifth divided into two bars. Bars ending in row of dark brown, usually slightly vertically extended or square blotches running between upper lateral line scales and E1 row, with two often contiguous blotches continuing row on caudal peduncle. Blotches vary in number, depending on whether divided like vertical bars or bridging two vertical bars

Dorsal fin in breeding females smoky with wide darker margin, sometimes with distinct light submarginal stripe. Some females with large black, slightly horizontally extended spot between dorsal spines $13^{\text {th }}-18^{\text {th }}$ or $12^{\text {th }}-17^{\text {th }}$, in one female very large dark spot between spines 14 and 20 and continuing on the soft rays; spot narrowly margined by hyaline zone. Soft portion of dorsal fin sometimes with few dark dots. In males, non-breeding females, and young, dorsal fin grayish with 3 (anteriorly) to 5 (posteriorly) irregular rows of dark spots.

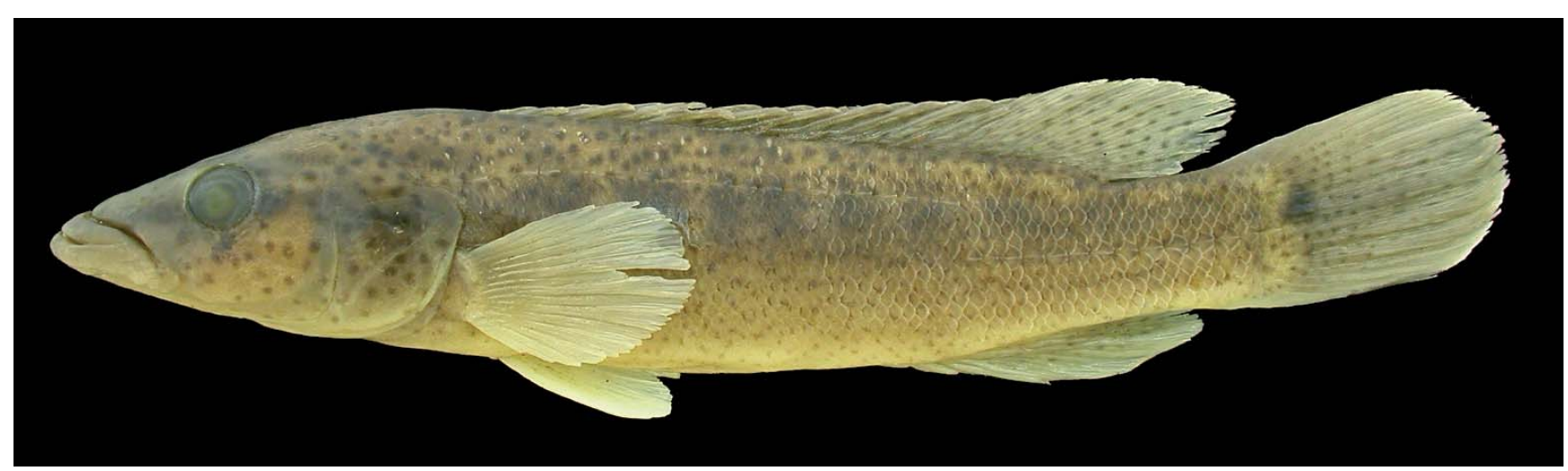

Fig, 10. Crenicichla punctata, male, MCP 21264, 125.0 mm SL, arroio da Gringa, rio Jacuí drainage, State of Rio Grande do Sul, Brazil. 
Table 5. Dorsal fin count frequencies in species of Crenicichla from southeastern Brazil. ${ }^{1}$ MNHN A9501 (126.0 mm), syntype of C. lacustris; ${ }^{2} \mathrm{FMNH} 54155$ (117.0 mm); holotype of C. dorsocellata; ${ }^{3}$ MZUSP 1781 (150.0 mm), paratype of C. biocellata; ${ }^{4}$ lectotype of C. mucuryna $(113.3 \mathrm{~mm}) ;{ }^{5}$ MZUSP 5385), paralectotype of C. muсuryna $(69.0 \mathrm{~mm}) ;{ }^{6}$ MZUSP $5386(110.0 \mathrm{~mm})$, paralectotype of C. mucuryna.

\begin{tabular}{|c|c|c|c|c|c|c|c|c|c|c|c|c|c|c|c|c|c|}
\hline & $\begin{array}{c}X X \\
11\end{array}$ & $\begin{array}{c}\mathrm{XX} \\
13\end{array}$ & $\begin{array}{c}\text { XXI } \\
11\end{array}$ & $\begin{array}{c}\text { XXI } \\
12\end{array}$ & $\begin{array}{c}\text { XXI } \\
13\end{array}$ & $\begin{array}{c}\text { XXI } \\
14\end{array}$ & $\begin{array}{c}\text { XXII } \\
10\end{array}$ & $\begin{array}{c}\text { XXII } \\
11\end{array}$ & $\begin{array}{c}\text { XXII } \\
12\end{array}$ & $\begin{array}{c}\text { XXII } \\
13\end{array}$ & $\begin{array}{c}\text { XXII } \\
14\end{array}$ & $\begin{array}{c}\text { XXIII } \\
11\end{array}$ & $\begin{array}{c}\text { XXIII } \\
12\end{array}$ & $\begin{array}{c}\text { XXIII } \\
13\end{array}$ & $\begin{array}{c}\text { XXIV } \\
11\end{array}$ & $\begin{array}{c}\text { XXIV } \\
12\end{array}$ & $\begin{array}{c}\text { XXIV } \\
13\end{array}$ \\
\hline С.. mисигуnа & 1 & & $6^{4,5}$ & & & & 6 & $4^{6}$ & 1 & & & & & & & & \\
\hline C. lacustris (except rio Doce lakes) & & & & & $7^{1}$ & 2 & & $2^{3}$ & 2 & $7^{2}$ & 4 & & 2 & 1 & & & 1 \\
\hline C. lacustris (rio Doce lakes) & & & & 5 & 2 & & & 1 & 12 & 5 & & & 1 & 1 & & & \\
\hline C. iguapina & & & & & 4 & 1 & & & 6 & 1 & & & 1 & & & & \\
\hline C. tingui & & & & & 4 & 2 & & & 1 & 3 & & & & & & & \\
\hline C. maculata & & 2 & & 4 & 5 & & & 2 & 17 & 16 & & 5 & 19 & 1 & 1 & 1 & \\
\hline C. punctata & & & & 1 & & & & & 14 & 5 & & & 2 & & 1 & & \\
\hline
\end{tabular}

Table 6. Anal fin, pectoral fin, and gill rakers count frequencies in the species of Crenicichla from southeastern Brazil. ${ }^{1} \mathrm{MNHN}$ A9501 (126.0 mm), syntype of C. lacustris; ${ }^{2} \mathrm{FMNH} 54155(117.0 \mathrm{~mm})$, holotype of C. dorsocellata; ${ }^{3}$ MZUSP $1781(150.0 \mathrm{~mm})$, paratype of C. biocellata; ${ }^{4}$ lectotype of $C$. mucuryna $(113.3 \mathrm{~mm}) ;{ }^{5}$ MZUSP 5385), paralectotype of C. mucuryna $(69.0 \mathrm{~mm})$; ${ }^{6}$ MZUSP 5386 (110.0 mm), paralectotype of C. muсuryna.

\begin{tabular}{|c|c|c|c|c|c|c|c|c|c|c|c|c|c|c|}
\hline & \multicolumn{5}{|c|}{ Anal fin rays } & \multicolumn{5}{|c|}{ Pectoral fin rays } & \multicolumn{4}{|c|}{ Gill rakers } \\
\hline & 7 & 8 & 9 & 10 & 11 & 14 & 15 & 16 & 17 & 18 & 8 & 9 & 10 & 11 \\
\hline C. mucuryna & 3 & $14^{4,5,6}$ & 1 & & & $1^{6}$ & $12^{4,5}$ & 2 & 1 & & $4^{4,6}$ & 9 & 4 & \\
\hline C. lacustris (except rio Doce lakes) & & $4^{3}$ & $24^{1,2}$ & 3 & & & 5 & 13 & 11 & & 1 & 6 & 14 & 8 \\
\hline C. lacustris (rio Doce lakes) & & 20 & 9 & & & & 3 & 17 & 4 & & 2 & 8 & 10 & 4 \\
\hline C. iguapina & & 1 & 11 & 1 & & & 1 & 10 & 2 & & & 3 & 4 & 6 \\
\hline C. tingui & & 1 & 6 & 3 & & & & 2 & 5 & 3 & & & & 1 \\
\hline C. maculata & & 2 & 29 & 42 & 1 & 1 & 3 & 31 & 10 & & 1 & 15 & 13 & 11 \\
\hline C. punctata & & 4 & 17 & 2 & & & 3 & 12 & 8 & & & 2 & 10 & 7 \\
\hline
\end{tabular}

Table 7. Lateral-line scale frequencies in species of Crenicichla from southeastern Brazil. ${ }^{1}$ MNHNA 9501 (126.0 mm), syntype of C. lacustris; ${ }^{2} \mathrm{FMNH} 54155$ (117.0 mm), holotype of C. dorsocellata; ${ }^{3} \mathrm{MZUSP} 1781$ (150.0 mm), paratype of C. biocellata; ${ }^{4}$ MZUSP $2526(113.3 \mathrm{~mm})$, lectotype of C. mucuryna; ${ }^{5}$ MZUSP 5386 (110.0 mm), paralectotype of C. mucuryna.

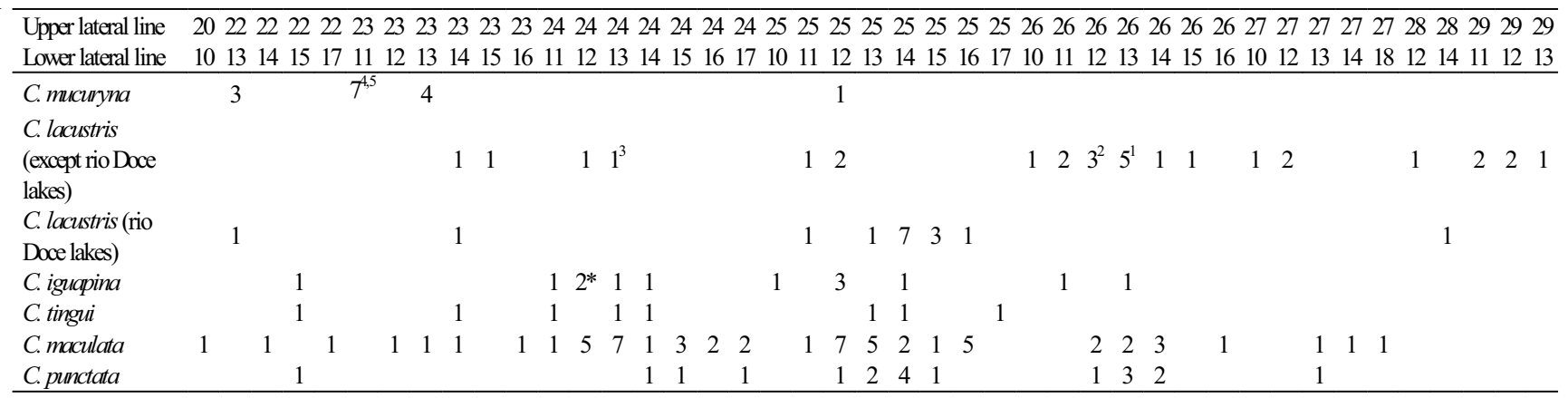

Anal fin grayish; in large males with numerous dark spots on posterior membranes; in young specimens and females only few dark spots distally. Pelvic fins whitish. Breeding females with immaculate caudal fin or only few dark dots. In males caudal fin vividly patterned with dark dots except posterodistally. Caudal spot black, rounded, situated between rays D1 and D4, and margined by light ring. Lateral line scales light with dark dot distally.

Small specimens up to $34.0 \mathrm{~mm}$ with dark band along middle of side, continuing postorbital stripe to caudal fin base. From this band 6-10 dark vertical bars extending dorsally to dorsal fin base or dorsal margin of caudal peduncle. Nuchal markings conspicuous, including two dark spots anterior to extrascapular series. Posttemporal spot black and conspicuous. Lateral spotting hardly evident and concentrated to lateral band area; spots absent from head. In specimens $47.0 \mathrm{~mm}$, few dark spots appear on opercle; specimens over $60 \mathrm{~mm}$ with well evident spots on head.
Stomach contents. Stomachs examined contained mollusc shells (bivalves) (MCP 11121, $149.6 \mathrm{~mm}$ ) and aquatic insect larvae (MCP 13510, $199.6 \mathrm{~mm}$ ).

Geographical distribution. Laguna dos Patos system, including the lagoa Mirim basin (Fig. 6).

Notes. Crenicichla punctata was redescribed by Lucena \& Azevedo (1989), who included C. polysticta in the synonymy. Although they did not comment further on this act, in so doing they acted as first revisers (ICZN, Art. 24), giving the name $C$. punctata priority over $C$. polysticta.

Neither Lucena \& Azevedo (1989) or we have examined the type series of $C$. polysticta. Hensel goes into such detail that we see no reason to doubt its identity with C. punctata. One of the syntypes, ZMB 7461, was figured by Ploeg (1991: fig. 160) 
Table 8. Vertebrae count frequencies in species of Crenicichla from southeastern Brazil.

\begin{tabular}{lllllllll}
\hline Abdominal & 19 & 19 & 19 & 20 & 20 & 20 & 21 & 21 \\
Caudal & 17 & 18 & 19 & 17 & 18 & 19 & 17 & 18 \\
\hline C. mucuryna & & 1 & & & & & & \\
C. lacustris & 1 & 1 & & 7 & 11 & & 2 & 2 \\
C. iguapina & & 1 & & & 4 & & & \\
C. tingui & & 2 & & & 3 & & & 1 \\
C. maculata & & 1 & 1 & 3 & 12 & 6 & & 3 \\
C. punctata & & 1 & & & 2 & & & \\
\hline
\end{tabular}

and fully agrees with C. punctata. Although Ploeg (1991: 12) states that the specimen (ZMB 7461) figured by him as $C$. polysticta is the 'single known specimen' and labels it holotype, it is clear from Hensel's description that it is based on the large specimen, $225 \mathrm{~mm}$, and one smaller specimen of $120 \mathrm{~mm}$. The other syntypes cannot be located in the ZMB collection (H.-J. Paepke, in litt., 13 Sep 1996). Ploeg (1991) included C. punctata in C. lacustris and figured the syntype, ZMB 7459 (Ploeg 1991: fig. 154), designated as lectotype of C. punctata by Lucena \& Azevedo (1989: 90). Crenicichla punctata is most similar to C. maculata and compared with that species above.

\section{Discussion}

The six species of Crenicichla distributed along the southeastern Brazilian coast fall into three distinct morphological groups: Crenicichla mucuryna is a relatively small species with a low scale count (56-63 in E1 row) and a color pattern dominated by narrow vertical bars, similar to Paraná drainage species, and may not be closely related to any of the other coastal species.

Crenicichla lacustris, C. iguapina, and C. tingui reach large sizes, especially C. lacustris, which attains $290 \mathrm{~mm}$. These species, representing $C$. lacustris of authors, all have a wide lateral band along the side, like the majority of Crenicichla species, and males are richly spotted on body and fins. Scale counts range from 60-75 (one specimen 57). Their respective distributions are allopatric along the coast from rio Buranhem to Santa Catarina north of the laguna dos Patos drainage.

Crenicichla punctata and C. maculata reach large sizes, attaining $290 \mathrm{~mm}$ and $211.5 \mathrm{~mm}$, respectively. Their combined distribution extends from the laguna dos Patos into Uruguayan tributaries of the laguna Mirim. Scale counts range from 56 to 75 . They feature a row of blotches along the side instead of a lateral band, in which respect they resemble the $C$. missioneira group of species recently described (Lucena \& Kullander, 1992) from the rio Uruguai drainage, particularly $C$. igara Lucena \& Kullander, 1992 and C. jurubi Lucena \& Kullander, 1992. Although they share a pattern of richly spotted body sides and fins with the C. lacustris-iguapina-tingui assemblage, and a similar sexual dimorphism with reduced spotting in females, a similar condition is found among C. missioneira group species. In $C$. igara and $C$. jurubi there is no sexual dimorphism in the extensive spotting; in C. missioneira, and C. tendybaguassu spotting is restricted to males and to the caudal peduncle.

The close similarity between C. punctata and C. maculata as expressed by characters in combination, and their vicarying distributions suggest that they may be closely related, and the same hypothesis may be advanced for $C$. tingui, $C$. iguapina and $C$. lacustris. The information available does not support and further relationship hypotheses, and the C. punctata and C. lacustris groups must be analysed with regard to a larger group of taxa and particularly the geographically close $C$. scottii and C. missioneira groups in the rio Uruguai drainage, and $C$. iguassuensis, and similar species in the rio Iguaçu drainage.

Species of the C. punctata and C. lacustris groups share with the $C$. missioneira and $C$. igara groups the presence of small dark spots covering the flanks and the associated sexual dimorphism of spotted males and immaculate or unspotted females. The presence of a series of dark blotches along the side is shared by the C. punctata, C. missioneira, and C. igara groups, and also with members of the $C$. reticulata group. We have identified one unique character of species of the $C$. missioneira and C. reticulata groups, C. vittata Heckel, 1840, and C. celidochilus. In these species, the females (in C. celidochilus, which is monomorphic, both sexes), have orange-red abdominal sides.

It is quite possible that the relationships of southeastern coastal drainage species have to be searched among various more interior Crenicichla groups which still have to be studied and which include several taxa with similar spot patterns in the rio Iguaçu and rio Paraná drainages. There is no indication that the C. lacustris-iguapina-tingui group would be most closely related to the $C$. punctata-maculata group; rather the pattern of blotches on the sides may be a synapomorphy of the $C$. punctatamaculata group with Uruguaian and Paranaean species. As $C$. mucuryna is also distinct from remaining coastal species, we find it probable, and a subject of further investigation beyond alpha taxonomic, that the southeastern coastal Crenicichla fauna is derive from at least two different sources - Uruguai and Paraná drainages - and it may be incorrect to speak, in a historical view, of a particular "coastal" Brazilian fauna of Crenicichla species.

Several of the coastal Brazilian species of Crenicichla, most notably C. mucuryna, and C. iguapina, have very limited geographical distributions within areas that are among the most densely populated in Brazil and therefore may be considered as vulnerable. With the traditional classification at least four of the species (C. lacustris, C. iguapina, C. maculata, and $C$. tingui) would have been lumped under the name of $C$. lacustris. With improved taxonomic resolution, the conservation status of these species can be addressed with better precision.

\section{Acknowledgements}

We are grateful to Heraldo Britski and Osvaldo Oyakawa (MZUSP), Gustavo Nunan and Paulo Buckup (MNRJ), Richard Vari (USNM), Barry Chernoff(FMNH), Ernst Mikshi (NMW), Wilson Costa (UFRJ), and Ulisses L. Gomes (DBAV) for access to collections and loan of specimens. Gustavo Nunan (MNRJ) loaned photos in his possession of the types of $C$. dorsocellata and fresh material of $C$. lacustris. Carlos Bizerril and Marcelo Aranha gave us fresh material of C. iguapina and C. tingui. The Conselho Nacional de Desenvolvimento Científico e Tecnológico $(\mathrm{CNPq})$ provided financial support for the collecting trip to the 
rio Itajaí-Açu drainage (Process \# 401256/91-0) (CAL). The Fundação de Amparo à Pesquisa do Rio Grande do Sul (FAPERGS) provided financial support to the project "Coastal Crenicichlas" (Process \# 93/02811-3) (CAL). The comments of two anonymous reviewers greatly improved this paper.

\section{Literature Cited}

Barel, C. D. N., M. J. P. van Oijen, F. Witte \& E. Witte-Maas. 1977. An introduction to the taxonomy and morphology of the haplochromine cichlids from Lake Victoria. Netherlands Journal of Zoology, 27: 333-389.

Bockmann, F \& G. Guazzelli. 2003. Family Heptapteridae. Pp. 406-431. In: Reis, R. E., S. O. Kullander \& C. J. Ferraris. Jr. (Eds.). Check list of the freshwater fishes of South and Central America. Edipucrs, Porto Alegre, 603 p.

Britski, H. A. 1969. Lista dos tipos de peixes das coleções do Departamento de Zoologia da Secretaria da Agricultura de São Paulo. Papéis Avulsos de Zoologia, 22(19): 197-215.

Castelnau, F. 1855. Poissons. In: Animaux nouveaux ou rares recueillis pendant l'expédition dans les parties centrales de l'Amérique du Sud, de Rio de Janeiro à Lima, et de Lima au Para; exécutée par ordre du gouvernement Français pendant les années 1843 à 1847. Bertrand, Paris, 112p.

Eigenmann, C. H. 1921. The American Characidae. Memoirs of the Museum of Comparative Zoology, Harvard, 43(3): 209-310.

Fowler, H. W. 1948. Os peixes de água doce do Brasil. Arquivos de Zoologia, 6: 1-204.

Garavello, J. C., H. Britski \& S. A. Schaefer. 1998. Systematics of the genus Otothyris Myers, 1927, with comments on geographic distribution (Siluriformes: Loricariidae: Hypoptopomatinae). American Museum Novitates, 3222: 1-19.

Haseman, J. D. 1911. An annotated catalog of the cichlid fishes collected by the expedition of the Carnegie Museum to central South America, 1907-10. Annals of the Carnegie Museum, 7(3-4): 329-373.

Hensel, R. 1870. Beiträge zur Kenntniss der Wirbelthiere Südbrasiliens. (Fortsetzung). Archive für Naturgeschichte, 36(1): 50-91.

Howes, G. 1982. Review of the genus Brycon (Teleostei: Characoidei). Bulletin of the British Museum (Natural History), Zoology Series, 43(1): 1-47.

International Comission on Zoological Nomenclature. 1999. International Code of Zoological Nomenclature, 4th ed. International Commission on Zoological Nomenclature, London, 306p.

Ihering R. 1914. Duas especies novas de Peixes da Fam. Cichlidae. Revista do Museu Paulista, 9: 333-337.

Kullander, S. O. 1982. Cichlid fishes from the La Plata basin. Part III. The Crenicichla lepidota species group. Revue Suisse Zoologie, 89: 627-661.

Kullander, S. O. 1986. The cichlid fishes of the Amazon river drainage of Peru. Swedish Museum of Natural History, Stockholm, 431p.

Kullander, S. O. 1990a. A new species of Crenicichla (Teleostei: Cichlidae) from the Rio Tapajós, Brazil, with comments on interrelationships of small crenicichline cichlids. Ichthyological Exploration of Freshwaters, 1(1): 85-94.

Kullander, S. O. 1990b. Crenicichla hemera (Teleostei: Cichlidae), a new cichlid species from the Rio Aripuanã drainage, Mato Grosso, Brazil. Ichthyological Exploration of Freshwaters, 1(3): 213-218.

Kullander, S. O. 1991. Crenicichla phaiospilus and C. percna, two new species of pike cichlids (Teleostei: Cichlidae) from the Rio Xingu, Brazil. Ichthyological Exploration of Freshwaters, 2(4): 351-360.

Kullander, S. O. 1997. Crenicichla rosemariae, a new species of pike cichlid (Teleostei, Cichlidae) from the upper Rio Xingu drainage, Brazil. Ichthyological Exploration of Freshwaters 7(3): 279-281.

Kullander, S. O. 2003. Family Cichlidae. Pp. 605-654. In: Reis, R. E., S. O. Kullander \& C. J. Ferraris Jr. (Org.). Check list of the freshwater fishes of South and Central America. Edipucrs, Porto Alegre, 729p.
Langeani, F. 1990. Revisão do gênero Neoplecostomus Eigenmann \& Eigenmann, 1888, com a descrição de quatro novas espécies do Sudoeste Brasileiro (Ostariophysi, Siluriformes, Loricariidae). Comunicações do Museu de Ciências PUCRS, Série Zoologia, 3(1): 3-31.

Lima, C. 2003. Subfamily Bryconinae. Pp. 174-181. In: Reis, R. E., S. O. Kullander \& C. J. Ferraris Jr. (Org.). Check list of the freshwater fishes of South and Central America. Edipucrs, Porto Alegre, $729 \mathrm{p}$.

Lima, F. C. T., L. R. Malabarba, P. A. Buckup, J. F. Pezzi da Silva, R. P. Vari, A. Harold, R. Benine, O. T. Oyakawa, C. S. Pavanelli, N. A. Menezes, C. A. S. Lucena, M. C. S. L. Malabarba, Z. M. S. Lucena, R. E. Reis, F. Langeani, L. B. Casatti, V. A. Bertaco, C. Moreira, \& P. H. F. Lucinda, 2003. Genera Incertae Sedis in Characidae. Pp. 106-169 In: Reis, R. E., S. O. Kullander \& C. J. Ferraris, Jr. (Org.), Check list of the freshwater fishes of South and Central America. Edipucrs, Porto Alegre, 729 p.

Lucena, C. A. \& P. Azevedo. 1989. Crenicichla punctata Hensel, 1870 uma espécie válida de ciclídeo para o sul do Brasil (Perciformes, Cichlidae). Comunicações do Museu de Ciências, PUCRS, Série Zoologia, Porto Alegre, 2(7): 87-105.

Lucena, C. A. S. \& S. O. Kullander. 1992. The Crenicichla (Teleostei: Cichlidae) species of the Uruguai River drainage in Brazil. Ichthyological Exploration of Freshwaters, 3(2): 97-160.

Malabarba, L. R. 1989. Histórico sistemático e lista comentada das espécies de peixes de água doce do Sistema da Laguna dos Patos, Rio Grande do Sul, Brasil. Comunicações do Museu de Ciências PUCRS, Série Zoologia, 2(8): 107-179.

Menezes, N. A. 1987. Três espécies novas de Oligosarcus Günther, 1864 e redefinição taxonômica das demais espécies do gênero (Osteichthyes, Teleostei, Characidae). Boletim de Zoologia da Universidade de São Paulo, 11: 1-39.

Miranda Ribeiro, A. 1918. Lista dos peixes Brasileiros do Museu Paulista. Primeira parte e Terceira parte. Revista do Museu Paulista, 10: 759-783.

Oyakawa, O. T., A. Akama \& A. M. Zanata. 2005. Review of the genus Hypostomus Lacépède, 1803 from rio Ribeira de Iguape basin, with description of a new species (Pisces, Siluriformes, Loricariidae). Zootaxa, 921: 1-27.

Papavero, N. 1975. Essays on the history of neotropical dipterology. Volume 1. Museu de Zoologia, São Paulo, 216p.

Pellegrin, J. 1904. Contribution à l'étude anatomique, biologique et taxinomique des poissons de la famille des Cichlidés. Memoires Societé Zoologie Française, 16(2-4): 41-400.

Pereira, E. H. L. \& R. E. Reis. 2002. Revision of the loricariid genera Hemipsilichthys and Isbrueckerichthys (Teleostei: Siluriformes) with descriptions of five new species of Hemipsilichthys. Ichthyological Exploration of Freshwaters, 13(2): 97-146.

Ploeg, A. 1991. Revision of the South American cichlid genus Crenicichla Heckel, 1840 with descriptions of fifteen new species and considerations on species groups, phylogeny and biogeography (Pisces, Perciformes, Cichlidae). Akademisch Proefschrift, Universiteit van Amsterdam, 152p.

Regan, C. T. 1905. A revision of the fishes of the South-American cichlid genera Crenacara, Batrachops, and Crenicichla. Proceedings Zoological Society London, 1(2): 152-168.

Regan, C. T. 1913. A synopsis of the cichlid fishes of the genus Crenicichla. Annals and Magazine Natural History, 11(65): 498-504.

Taylor, W. R. \& Van Dyke, G. 1985. Revised procedures for staining and clearing small fishes and other vertebrates for bone and cartilage study. Cybium, 9(2): 107-119.

Weber, C. 2003. Subfamily Hypostominae. Pp. 351-372. In: Reis, R. E., S. O. Kullander \& C. J. Ferraris Jr. (Org.). Check list of the freshwater fishes of South and Central America. Edipucrs, Porto Alegre, 729p.

Received September 2005 Accepted March 2006 